\title{
Conjunction meaning can modulate parallelism facilitation: Eye-tracking evidence from German clausal coordination
}

\author{
Pia Knoeferle ${ }^{*, 1}$ \\ Cognitive Interaction Technology Excellence Cluster \& Department of Linguistics, University of Bielefeld, Germany
}

\section{A R T I C L E I N F O}

\section{Article history:}

Received 1 September 2010

revision received 7 May 2014

\section{Keywords:}

Clausal parallelism

Coordinating conjunction

Eye tracking

Sentence comprehension

Priming

\begin{abstract}
A B S T R A C T
In and-coordinated clauses, the second conjunct elicits faster reading times when it parallels (vs. does not parallel) the first in constituent order. This paper examined whether such parallelism facilitation results from simple constituent order priming from the first to the second clause, or whether it can be modulated through the linguistic context (the conjunction and clausal relations). Three eye-tracking experiments on German assessed this issue by manipulating conjunction meaning and type within subjects (resemblance: 'and' vs. adversative: 'but' or 'while'; coordinating: 'and' and 'but'; subordinating: 'while'), and by varying the clausal relations between experiments. Clausal parallelism facilitation was reduced when syntactic dependence of the clauses from a superordinate verb reinforced their coherence, and semantic expectations for 'but' and 'while' were violated through the parallel constituent order and thematic role relations of noun phrases. By contrast, it was not reduced when the same expectations were satisfied through other sentence constituents (temporally contrastive adverbs) and when the coordination involved matrix clauses. The contextual modulation of parallelism facilitation rules out simple priming as the only underlying mechanism. The observed facilitation rather reflects compositional processing of the coordinands and the conjunction in the linguistic context.
\end{abstract}

(c) 2014 Elsevier Inc. All rights reserved.

\section{Introduction}

An increasing number of studies is beginning to examine sentence comprehension mechanisms by looking at how recently interpreted linguistic structure influences ensuing comprehension. Some of these studies have examined what has been dubbed structural 'priming' effects (e.g., Arai, Gompel, \& Scheepers, 2007; Branigan, Pickering, \& McLean, 2005; Scheepers \& Crocker, 2004; Traxler, 2008), that is the "tendency to [...] better process

\footnotetext{
* Address: Cognitive Interaction Technology Excellence Cluster, Inspiration 1, Room 2.036, Bielefeld University, D-33615 Bielefeld, Germany. Fax: +49 5211066560 .

E-mail address: knoeferl@cit-ec.uni-bielefeld.de

1 The present studies were conducted while the author was in the Department of Computational Linguistics at Saarland University, Germany.
}

a current sentence because of its structural similarity to a previously experienced ('prime') sentence" (Pickering \& Ferreira, 2008, p. 427).

Other studies have examined 'parallelism effects', by which we mean processing facilitation within a given sentence when two conjuncts are similar in their structure. Not unlike priming, the structure of the second conjunct is processed with greater ease when it resembles the structure of the first conjunct (active-active coordination, (1a)) than when it doesn't (active-passive coordination, (1b), e.g., Frazier, Taft, Roeper, \& Clifton, 1984).

(a) The tall gangster hit John and the short thug hit Sam.

(b) The tall gangster was hit by John and the short thug hit Sam. 
At first blush, these two kinds of repetition appear related through the facilitative effect that they procure and through the pervasiveness of their effects beyond the structural level. Priming during sentence comprehension also emerged for semantic similarity and lexical repetition (e.g., Kutas, 1993), and parallelism effects for phonology, definiteness (Carlson, 2001; Frazier et al., 1984), and animacy (Carlson, 2001; Frazier et al., 1984) amongst others. Both of these phenomena also occur with and without verb repetition. Verb repetition between a prime and target sentence was essential in eliciting priming effects when the primed structure was part of the verb's lexical entry (e.g., arguments, Arai et al., 2007) while priming of nonargument structure (adjuncts) did not depend upon verb repetition (Traxler, 2008). For parallelism, facilitation has likewise been observed with (e.g., Frazier et al., 1984) and without verb repetition (e.g., Knoeferle \& Crocker, 2009).

Based on these similarities, it would seem parsimonious to assume that priming and parallelism effects implicate the same (priming) mechanism (of which more below). However, an argument in favor of a distinct parallelism mechanism would appear justified if - unlike priming - parallelism effects depended upon the linguistic context (e.g., coordination). Parallelism effects originally emerged in a specific syntactic environment (and-coordination), prompting speculation that their emergence might depend upon that context and involve more than just repetition. Initial empirical results seemed to corroborate this view. In andcoordination, facilitation manifested itself through faster reading times for the second conjunct of structurally parallel (e.g., a strange man and a tall woman) than non-parallel noun phrases (a man and a tall woman). By contrast, when the same two noun phrases filled verb argument slots, no parallelism effects emerged ( $a$ tall woman was no faster after $A$ strange man noticed than after $A$ man noticed; Apel, Knoeferle, \& Crocker, 2007; see Frazier, Munn, \& Clifton, 2000). This finding was taken to suggest that parallelism effects depend upon the presence of and, and cannot be accommodated by a priming mechanism alone.

One concern, however, was that the non-coordinate construction involved grammatical function changes in the critical noun phrases (subject vs. object of the verb), and that this could have eliminated parallelism facilitation. When Sturt, Keller, and Dubey (2010) controlled for grammatical function and noun phrase meaning differences, participants' first pass, regression path, and total reading times were shorter when two noun phrases were parallel relative to non-parallel in their structure, independent of whether these noun phrases were coordinated by and ( $a$ difficult to read book and a risky to cross street) or not (e.g., A demanding boss said that a lazy worker...). Their findings showed that - at least for noun phrase coordination - parallelism facilitation can occur outside of andcoordination, suggesting a priming mechanism is sufficient to accommodate these effects. However, it remains an open issue whether this is also the case for other (e.g., clause-level) parallelism effects.

A related question is whether the meaning and type of the coordinating conjunction modulates parallelism facilitation. Staub and Clifton (2006), for instance, have shown that readers integrate conjunctions incrementally into the emerging sentence interpretation. When or coordinated either two clauses or noun phrases, participants' post-conjunction reading times were faster if they had previously read the word either. Thus, the presence of either led readers to predict the upcoming coordination structure. Against this background, we can assume that the interpretation of the first clause in a coordinate structure together with the ensuing conjunction affects comprehenders' expectations about the second conjunct. What we do not yet know is whether parallelism effects are sensitive to such contextual modulation. For clausal coordination in particular, compositional semantic interpretation of the conjuncts in their linguistic context might play a crucial role, a view espoused by a recent account of parallelism effects (Knoeferle \& Crocker, 2009, of which more below). If parallelism effects were indeed modulated by conjunction meaning this would seem to implicate more than just priming through (structural) repetition.

The present paper examined this issue in three sentence-completion and three eye-tracking experiments by manipulating the meaning and type of the conjunction for sentences such as those in (2). These examples are from a study by Knoeferle and Crocker (2009). For sentence (2a) the two clauses are non-parallel and for (2b) they are parallel in constituent order (object-subject-and-objectsubject). Parallelism facilitation emerged in total times on den Ringer ('the wrestler') and in regression path times during the next noun phrase der Erzfeind ('arch-enemy', see (2) and Exp. 2 in Knoeferle \& Crocker, 2009). The study also manipulated structural markedness and found elevated reading times when the second conjunct was in marked (object-subject) compared with unmarked (subjectobject) order (Knoeferle \& Crocker, 2009). There was no strong evidence that parallelism effects varied by structural markedness although descriptively, parallelism facilitation was apparent for unmarked structures while for the marked ones, reading times were longer for parallel than non-parallel constituent order $(F s<2)$.

(2)

(a) Vor einer Stunde bezwang der Fechter (subj) den Gegner (obj) und gerade besiegt den Ringer (obj) der Erzfeind (subj), wie der Journalist schreibt.

'An hour ago defeated the fencer (subj) the adversary (obj) and currently overwhelms the wrestler (obj) the arch-enemy (subj), as the journalist writes.'

(b) Vor einer Stunde bezwang den Fechter (obj) der Gegner (subj) und gerade besiegt den Ringer (obj) der Erzfeind (subj), wie der Journalist schreibt.

'An hour ago defeated the fencer (obj) the adversary (subj) and currently overwhelms the wrestler (obj) the arch-enemy (subj), as the journalist writes.'

Does simple priming alone bring about these constituent order parallelism effects or are they sensitive to the meaning and type of the conjunction? In what follows, I first discuss a 'simple' priming account according to which 
conjunctions do not contribute to parallelism facilitation. I then introduce the conjunctions that I manipulated (und 'and', aber 'but', and während, 'while') and outline how they might contribute to coordinate structure processing. Finally, I outline a compositional semantic interpretation account of constituent order parallelism, and give an overview of (the hypotheses for) the present experiments.

\section{The simple priming account of parallelism}

The findings by Sturt and colleagues of parallelism effects outside of coordination provide evidence for what I will dub a 'simple priming' account of parallelism, a version of which has been implemented in a probabilistic rule-based model (Dubey, Sturt, \& Keller, 2009). The probability of a rule in this model depends upon rule application. Application of a rule increases its probability, which in turn affects the ease of using that rule. Rule probability is mapped onto reading times using 'surprisal' (Hale, 2001), whereby a recently applied rule has a high probability, implicating low surprisal and short reading times during comprehension.

Note that surprisal in this account is computed from a simple probabilistic context free grammar (PCFG) model with non-lexicalized rules but without adopting the full independence assumptions of a PCFG. A PCFG uses syntactic rules of the form $\mathrm{S} \rightarrow \mathrm{NP}$ VP and NP $>$ Det N, N $>$ man with non-terminals on the left, and with either terminals or non-terminals on the right-hand side. In this notation, the ' $S$ ' stands for sentence, and the arrow indicates that a sentence can consist of a noun phrase ('NP') and a verb phrase ('VP'), and a noun phase of a determiner ('Det') and a noun (' $\mathrm{N}$ '). Prior rule probability can influence ensuing rule use (see Dubey et al., 2009, p. 342). Lexical information, however, is not part of the non-terminals (e.g., NP, VP) and can thus not influence rule probability and parsing decisions.

Crucially on that account, structural representations of the first conjunct prime constituent order processing in the second conjunct through increased activation of the associated rule. Since lexical information does not affect parsing in a non-lexicalized PCFG, conjunction meaning cannot modulate the probability of applying a constituent order rule. The simple priming account was motivated by results from noun phrase coordination. Whether it extends to arguably more complex clausal coordination and parallelism in the constituent order and thematic role relations remains an open question.

\section{Conjunction meaning and type}

If we consider the possibility that conjunctions could, in principle, modulate constituent order parallelism effects, one way in which this could happen is through the distinct semantic relations that different conjunctions establish between the coordinands (e.g., Schiffrin, 1987, see Segal \& Duchan, 1997). Here I discuss the three manipulated conjunctions (German und 'and', aber 'but', and während, 'while').

The coordinating conjunction and signals semantic similarity of the coordinands and it establishes 'parallel resemblance' relations according to coherence frameworks (e.g., Kehler, 1995, 1996, see also Halliday \& Hasan, 1976). Kehler (1995), for instance, assumes that readers recognize commonalities among a set of entities in the first clause and a set of entities in the second, and-coordinated clause, and in this way establish discourse coherence between the two clauses (Kehler, 1995, p. 12ff.). In (2b), for instance, the common relation of the entities 'the fencer (obj) the adversary (subj)' and 'the wrestler (obj) the arch-enemy (subj)', would be that an opponent does something to another athlete (a fencer; a wrestler). If the conjunction were 'but', instead of 'and', coherence theory would predict that comprehenders attempt to establish semantically contrastive relations between (entities in) the first and second clause of the coordinate structure.

Postulates of meaning differences between these conjunctions and resulting constraints on the coordinands receive some support from offline studies on the interpretation of discourse connectives. In a first experiment by Segal, Duchan, and Scott (1991), participants retold a story in their own words using discourse connectives from a given set (Experiment 1). In a second study, participants had to chose a label for the logical relationship established by connectives between phrases in a simple story (e.g. 'adversative', expressing a contrast between the phrases, or 'additive', expressing the addition of phrases, Experiment 2). In a third study, participants saw the phrases without the connectives and had to choose a label for their relationship. Across these three studies, and/additive choices were more frequent than adversative choices. Clauses were judged as additive more often with and (vs. without and), and as contrastive more often with but (vs. without but; Segal et al., 1991). Studies on language development further suggested that and is learned earlier (2527 months) than but (32-38 months, see, e.g., Bloom, Lahey, Hood, Lifter, \& Fiess, 1980). And encoded mostly additive relations in child speech (followed by temporal, causal, and adversative relations), while but appeared with contrastive meaning. By contrast, in a corpus study, Spenader and Lobanova (2009) found that but occurs more often with contrastive $(0.85)$ than other relations (e.g. cause-effect: 0.44 ). Thus, the coordinating conjunctions and and but occur with distinct meaning relationships between the conjuncts, and could, in principle, elicit expectations of similar and contrastive semantic relations respectively during comprehension.

The third conjunction that I manipulated was German während ('while'), a subordinating conjunction which, unlike coordinating conjunctions, is "structurally asymmetric" and does not necessarily link morphosyntactically similar constituents (Blühdorn, 2008, p. 6; see, Pasch, Brauße, Breindl, \& Waßner, 2003). For instance, one cannot extract an element from just one conjunct in a coordinate structure (e.g., in Marta leads the group and drives a beamer, moving just one coordinand out of the coordination results in a non-felicitous sentence *What did Marta lead and drive the beamer?, Ross, 1967). For während, by contrast, that

\footnotetext{
2 See also Lakoff, 1971, on but conjoining two contrastive clauses; Blakemore, 1989, for a discussion of but in relevance theory; Lang \& Umbach, 2002, on contrast in grammar.
} 
operation is possible: Marta led the group while driving a beamer (What did Marta lead while driving a beamer?).

Während can have either an adversative meaning similar to aber ('but'), or a temporal meaning (e.g., Lohnstein, 2005, see also Clément \& Thümmel, 1996). Its meaning is adversative when the two clauses have a common integrator and one clausal event does not subsume the other. A 'common integrator' refers to a superordinate category that subsumes both conjuncts (e.g., Lang, 1977, see Fabricius-Hansen \& Ramm, 2008). For Der Fechter besiegt den Gegner, während der Ringer seinen Kontrahenten überwältigt, ('The fencer defeats his opponent whereas the wrestler overwhelms his adversary'), the common integrator is a sportsman interacting with an opponent. The events ('fencer defeats opponent' vs. 'wrestler overwhelms adversary') do not subsume one another, thus rendering an adversative reading of 'while' possible (see, e.g., Lohnstein, 2005 for further discussion). Corpus analyses further revealed that 'while' occurs more often contrastively (0.15) than with cause-effect relations $(0.09$, see Table 1 in Spenader and Lobanova (2009)) although overall it occurred less often with contrastive relations than 'but'.

\section{The compositional semantic interpretation account}

To the extent that the semantic relations established by the meaning of a conjunction in the context of the first conjunct affect the processing of the second conjunct in real time, they could modulate parallelism facilitation. Below I outline a recent account according to which constituent order parallelism effects implicate more than just structural repetition, and which accords a central role to the conjunction (Knoeferle \& Crocker, 2009).

The account assumes that after comprehenders have interpreted the first conjunct, distinct phonological, syntactic and semantic representations (or features) of that interpretation are active in working memory. ${ }^{3}$ Next, and is encountered and triggers expectations of parallel structure. ${ }^{4}$ The account assumes an increase in the likelihood of particular structures as a function of the linguistic context. For instance, upon encountering and, the structures encountered in the first conjunct (e.g. object-subject order) would be assigned a greater likelihood of re-occurring, thus lowering the surprisal, and thereby reading times, when a parallel structure is subsequently encountered (see Knoeferle \& Crocker, 2009). The key factors in the account are the representations that are parallel or primed and their lexical dependencies; in the case of parallelism the presence of a coordinating conjunction that expresses likeness of conjuncts; and the determination (through compositional interpretation) of structure(s) in the first conjunct that are relevant for parallel structure facilitation. However, the proposal has not yet specified precisely how distinct con-

\footnotetext{
3 For a discussion of alternatives such as copy- $\alpha$ (Frazier \& Clifton, 2001) or pointers to representations in memory (Martin \& McElree, 2008) see Knoeferle and Crocker (2009).

4 See Callahan, Shapiro, and Love (2010) for evidence on the re-activation of verb meaning in response to a related vs. unrelated probe word following the conjunction and, and see Poirier, Walenski, and Shapiro (2011) for relevant evidence on anaphora processing.
}

junctions could modulate constituent order parallelism effects.

One possibility is that 'and' and 'but' (because of the different semantic relations that they establish) trigger expectations of distinct parallel and non-parallel/contrastive structures respectively at all linguistic levels (phonological, syntactic, and semantic). While this assumption may seem unmotivated at first glance, we should acknowledge that we know little about the kinds of expectations and associations elicited by these conjunctions. Indeed, most existing research on priming in language processing has focused on structure related to verbs and nouns and on how verb repetition can boost argument structure priming (e.g., Ledoux, Traxler, \& Swaab, 2007; Pickering \& Branigan, 1998; Traxler, 2008). Regarding conjunctions, for instance, it has recently been shown that 'and' and 'but' are associated with distinct spatial configurations of objects (Guerra, Marghetis, \& Knoeferle, 2013). In a drawing task, participants could choose objects (different stars and frames) from an inventory and followed verbal instructions to depict a relationship (e.g., 'and' or 'but') between them. They drew the objects more often than chance close together and within a single depicted frame for 'and' than 'but'. By contrast for 'but', they represented the relationship more often than chance by means of size differences between objects. Ratings on a scale from 1 to 7 of the fit between a linguistic term such as 'and/but' and object drawings (e.g., close together vs. differentlysized objects) corroborated these results.

These results suggest that 'and' relates two words and objects differently from 'but'. 'And' seems to highlight that two things belong close together and should be similar and 'but' expresses that two things are differently sized (and thus not the same). Such relational differences between these two conjunctions could apply to different aspects of both linguistic and non-linguistic stimuli including how similar these stimuli are regarding their linguistic properties (e.g., phonology, syntax, and semantics). On that assumption, conjunctions could constrain coordinate structures in more than just their meaning. 'And' could trigger a comparison of the conjuncts for similarity pertaining to phonological, syntactic, semantic, visual, and motor representations. By contrast, 'but' could constrain its coordinands to distinct and perhaps contrastive phonological, syntactic, semantic, visual, and motor representations. At the very least, however, 'but' should elicit expectations of similarity to a lesser extent than 'and'. If the type of conjunction (subordinating vs. coordinating) also contributes towards procuring parallelism facilitation, then we should see a similar pattern for 'while'-subordination as for 'but'-coordination. Coordinating conjunctions restrict the ensuing syntactic space more than subordinating conjunctions (e.g., extracting a linguistic element from just one of the two conjuncts is not possible in coordination but is possible in subordination). 'While', is one instance of a subordinating conjunction, and if these subtle differences in syntactic constraint impact parallelism effects we should see a reduced modulation of parallelism effects for 'while' than 'but'. Alternatively, the meaning of the conjunction may be what modulates constituent order parallelism 
facilitation, in which case we should see no difference in the reading time pattern across studies for 'while' compared with 'but'.

In summary, to the extent that conjunctions are associated with parallelism/non-parallelism (i.e., contrast) at different levels of linguistic and non-linguistic structure, it would seem possible that they can modulate constituent order parallelism effects, amongst others. Comprehenders interpret the first conjunct, and phonological, syntactic, and semantic representations are active in working memory. Next, 'and' is encountered and integrated into the unfolding interpretation, and the representations active during processing of the first conjunct would be assigned a greater likelihood of re-occurring, thus lowering surprisal, and thereby reading times; by contrast, for 'but', nonparallel and thus contrastive structures would be assigned an increased likelihood. When readers encounter parallel structures following 'but', their reading times would thus increase, and they would decrease for non-parallel or contrastive structures. In this way, the account can accommodate parallelism effects through the interpretation of the first conjunct and the conjunction.

Other instantiations of the compositional account are, in principle, possible, but distinguishing between these is not the goal of the present paper (but see the General Discussion). Rather, the present research strives to assess whether the conjunction can modulate constituent order parallelism facilitation. To the extent that it can, simple non-lexicalized priming would appear insufficient to accommodate these parallelism effects.

\section{The present study}

To summarize, this paper examines whether the relationship (resemblance vs. contrastive) established by a coordinating conjunction can affect constituent order parallelism effects in clausal coordination, and considers the effects of the type of conjunction (coordinating vs. subordinating). Consider the predictions of the two (simple priming and semantic interpretation) accounts for the sentences in (2) (see also Table 1): For 'and'-coordination, both the semantic interpretation and the simple priming account predict faster reading times at the two noun phrases in the second conjunct for parallel compared with non-parallel constituent order. On the priming account, this facilitation occurs through structural repetition alone and to the extent that the existing findings generalize, we might expect to see these effects in first-pass times (e.g., Sturt et al., 2010). On the semantic account, readers integrate 'and' with the syntactic and semantic representations of the two clauses. 'And' establishes a resemblance relation, and expectations of resemblance are confirmed by the two coordinands for the parallel conditions only (Table 1, (a)). This is because for the parallel conditions the conjuncts are similar in both constituent order (object-subject and object-subject) and thematic role relations (a fencer/wrestler defeats an opponent). For non-parallel conditions, the conjuncts are dissimilar on both of these counts. In terms of the time course, if the findings on clausal parallelism by Knoeferle and Crocker (2009), replicate, then we should see effects in total times at NP3 and in regression path times at NP4 for the sentences in Table 1.

For 'but'-coordination and 'while'-subordination, the simple priming and the semantic account make distinct predictions. The simple priming account predicts the same parallelism facilitation as for 'and'-coordination (neither conjunction meaning nor type should have an effect on parallelism effects in the reading times). This is because the only change concerns the conjunction, which, according to simple priming, does not affect structural repetition; the clauses remain otherwise unchanged (i.e., for Table 1 , (b) and (d)). On the semantic account, by contrast, comprehenders integrate the syntactic and semantic representations of the first conjunct with conjunction meaning. 'But' and 'while' establish contrastive relations, and should elicit expectations of contrastive syntactic and semantic representations. For non-parallel constituent order, this expectation is met, which, accordingly, should elicit lower surprisal and faster reading times than for parallel constituent order. Parallel constituent order and thematic role relations, by contrast, conflict with expectations of contrast and should elicit higher surprisal and reading times. The semantic account makes no predictions regarding conjunction type but to the extent that the syntactic relations between the conjuncts affect parallelism facilitation, we should see differences in reading times for the second conjunct for German 'but' (coordinating) relative to 'while' (subordinating).

Three eye-tracking studies manipulated conjunction meaning (und 'and' vs. aber, 'but': Experiments 1 and 2) as well as conjunction meaning and type (und 'and' vs. während 'while': Experiment 3). Three corresponding sentence completion studies provided insight into comprehenders'

Table 1

Example item sentence set for Experiment 1. 'NP1' through 'NP4' indicate the four critical noun phrase regions.

\begin{tabular}{|c|c|}
\hline Condition & Sentences \\
\hline $\begin{array}{l}\text { (a) 'and', parallel } \\
\text { (b) 'but', parallel }\end{array}$ & $\begin{array}{l}\text { Vor einer Stunde bezwang | den Fechter (obj) }\left.\right|_{\mathrm{NP1}} \text { der Gegner (subj) }\left.\right|_{\mathrm{NP2}} \text { und / aber gerade besiegt } \mid \text { den Ringer (obj) }\left.\right|_{\mathrm{NP3}} \text { der } \\
\text { Erzfeind (subj) }\left.\right|_{\mathrm{NP4}} \text {, wie der Journalist schreibt. } \\
\text { 'An hour ago defeated | the fencer (obj) }\left.\right|_{\mathrm{NP1}} \text { the adversary (subj) }\left.\right|_{\mathrm{NP2}} \text { and currently overwhelms } \mid \text { the wrestler (obj) }\left.\right|_{\mathrm{NP3}} \text { the } \\
\text { arch-enemy (subj) }\left.\right|_{\mathrm{NP4}} \text {, as the journalist writes.' }\end{array}$ \\
\hline $\begin{array}{l}\text { (c) 'and', non-parallel } \\
\text { (d) 'but', non-parallel }\end{array}$ & $\begin{array}{l}\text { Vor einer Stunde bezwang } \mid \text { der Fechter (subj) }\left.\right|_{\mathrm{NP} 1} \text { den Gegner (obj) }\left.\right|_{\mathrm{NP2}} \text { und / aber gerade besiegt } \mid \text { den Ringer (obj) }\left.\right|_{\mathrm{NP3}} \text { der } \\
\text { Erzfeind (subj) }\left.\right|_{\mathrm{NP} 4} \text {, wie der Journalist schreibt. } \\
\text { 'An hour ago defeated | the fencer (subj) }\left.\right|_{\mathrm{NP1}} \text { the adversary (obj) }\left.\right|_{\mathrm{NP} 2} \text { and / but currently overwhelms } \mid \text { the wrestler (obj) } \\
\left.\right|_{\mathrm{NP3}} \text { the arch-enemy (subj) }\left.\right|_{\mathrm{NP} 4} \text {, as the journalist writes.' }\end{array}$ \\
\hline
\end{tabular}


expectations of constituent order parallelism and semantic similarity for the second clause. Experiment 1 examined the effects of German und ('and') relative to aber ('but') in main clause coordination. Experiment 2 examined the same issue in sub-ordinate clause coordination. Experiment 3 compared the effects of German und ('and') relative to während ('while') in sub-ordinate clause coordination. Based on prior related research, parallelism effects should appear in total times on the first noun phrase and in regression path and total times on the second noun phrase of the second conjunct (see Knoeferle \& Crocker, 2009).

The rationale for the change in sentence structure from Experiment 1 to Experiments 2 and 3 was to examine parallelism effects in a linguistic context that increases the coherence between the coordinands. When two coordinands are the complements of a common superordinate verb, they depend on the same lexical item and share positions in the syntactic analysis. This could strengthen their semantic coherence (see, e.g., Matthiessen \& Thompson, 1988; but see, Blühdorn, 2008) and accentuate effects of conjunction meaning on clausal integration and thereby parallelism effects.

The structural changes ensured further that the target noun phrases in the second conjunct immediately succeeded the conjunction (unlike in Experiment 1 where a temporal adverb and verb intervened). The adjacency of the conjunction and the noun phrases should further strengthen potential effects of the conjunction on parallelism facilitation, since in this way expectations elicited by the conjunctions can immediately be applied to the target noun phrases (rather than to other intervening sentence content). Overall, these experiments thus assessed to which extent the linguistic context modulates parallelism effects, with a view to assessing whether they are best accommodated by simple non-lexical priming or by a mechanism that draws on both coordinand representations and representations of their linguistic context.

\section{Experiment 1}

Experiment 1 examined the processing of German constituent order parallelism in German main clause coordination, contrasting und ('and')-coordination with aber ('but')-coordination (see Table 1 and Appendix A for example stimuli). If a priming mechanism underlies both 'and' and 'but'-coordination, then reading times should be faster at the noun phrases in the second conjunct for parallel than non-parallel constituent order independent of the conjunction.

\section{Method}

\section{Participants}

Thirty-two native speakers of German with normal or corrected-to-normal vision received 7.50 euros each for participating in the experiment.

\section{Materials and design}

Table 1 shows an example sentence set for the 32 critical items from Experiment 2 by Knoeferle and Crocker (2009, see Appendix). I manipulated conjunction meaning and parallelism. Conjunction refers to whether the coordinating conjunction was und ('and') or aber ('but'). Parallelism identifies whether the constituent order of the second clause was parallel to that of the first clause ('parallel') or not ('non-parallel'). Crossing conjunction and parallelism created four conditions (Table 1, (a-d)). Und ('and') was somewhat more frequent than aber ('but', Baayen, Pipenbrock, \& Gulikers, 1995) in line with existing evidence (e.g., Segal et al., 1991); the length of the other words and their lemma frequency was identical between conditions within an item.

Assigning item-condition combinations to lists following a Latin Square design resulted in four lists. Each list contained 32 experimental items and 95 filler items. Each list further contained an equal number of experimental trials in each condition, and only one condition of an item. At least one (out of 95) filler trials separated consecutive experimental trials. The order of trials was pseudorandomized for each participant.

A pen-and-pencil study ascertained the completion preferences of 12 participants that did not take part in Experiment 1. The participants completed sentence fragments (ending at the verb in the second conjunct, '.... overwhelms___ see Table 1). The post-verbal NP3 was not included since it would have fully disambiguated the constituent order of the second conjunct as object-subject. There were four lists and item-condition combinations were assigned to them following a Latin Square design.

Completions for the fragments up to the verb were coded as 'subject-object', 'object-subject', or 'other' (ungrammatical, see the Supplementary materials for more details). Overall, subject-object completions were more frequent (87.68\%) than object-subject completions (6.83\%, see Table $4 ; L R \chi^{2}(\operatorname{subj})=313.57, p<.0001 ; L R \chi^{2}$ $($ item $)=313.57, p<.0001)$. While the markedness of the first clause did not affect the constituent order of the completions $(p s>.2)$, conjunction $\operatorname{did}\left(L R \chi^{2}(\mathrm{subj})=5.24\right.$, $p<.05 ; L R \chi^{2}$ (item) n.s.). Object-subject completions were more frequent for 'but' (9.5\%, Table 4) compared with 'and' coordination (4.2\%) and subject-object were somewhat more frequent for 'and' (90.1\%) than 'but'coordination (85.3\%). These differences were small, however, and it is thus unclear whether they will affect reading time means.

Completions were also coded for thematic role similarity with the first conjunct ('similar' vs. 'contrastive' vs. 'ambiguous'). The coding was possible since most completions involved at least one pronoun that referred back to a noun phrase in the first conjunct. Markedness affected the semantic similarity of the completions $\left(L R \chi^{2}(\mathrm{subj})=4.1\right.$, $p<.05, L R \chi^{2}$ (item) n.s.), as did the conjunction $\left(L R \chi^{2}\right.$ $(\mathrm{subj})=7.83, p<.05, L R \chi^{2}$ (item) n.s.). More completions were semantically contrastive after subject-object (30.7) than object-subject word order (25.3). There were more contrastive completions for 'but' (32\%) than for 'and' (23.9), while the semantic similarity of the completions was similar across conjunctions (see Table 4). As with the syntactic completions, however, the differences were numerically small and it is thus unclear whether they will affect reading time means. To the extent that these 
findings generalize to comprehension, the conjunction should have relatively small effects on parallelism facilitation at the noun phrases in the second conjunct.

\section{Procedure}

Sentences were presented in black on a white background on a 21 -inch monitor in 24 pt font. An SMI Eye-Link I head-mounted eye tracker monitored participants' eye movements at $250 \mathrm{~Hz}$. Participants were seated approximately $50 \mathrm{~cm}$ from the screen and received written instructions. Each trial started with a central fixation dot that participants focused on to permit the experimenter to perform a drift correction if necessary. Then, participants were asked to shift their gaze to a black square that appeared at the position of the first word in the sentence (presentation duration: $1500 \mathrm{~ms}$ ). This ensured that participants started reading at the beginning of the sentence. Participants read silently, and indicated successful comprehension by pressing the down-arrow button on the keyboard. Forty-six of 95 filler trials were followed by a yes/no question that participants replied to by pressing either the left-arrow key ('no') or the right-arrow key ('yes'). After the experiment, the experimenter debriefed the participants. The experiment lasted approximately $45 \mathrm{~min}$ with a short break after approximately half of the trials.

\section{Analysis}

For the eye-gaze analyses, contiguous fixations of less than $100 \mathrm{~ms}$ were pooled and incorporated into larger fixations: blinks and out-of-range fixations (i.e., with invalid negative $x / y$-coordinates) were added to previous fixations. Vertical drift in the eye-gaze data was corrected with a Perl script. Three gaze measures were chosen based on prior findings (Knoeferle \& Crocker, 2009; Sturt et al., 2010): First-pass time is the duration of all fixations in a region from first entering to first leaving it. Regression-path duration (RPD) is the duration of gaze in a region or to its left from first entering but before leaving that region to the right. It has been interpreted as time to sufficiently process text before reading on (e.g., Konieczny, Hemforth, Scheepers, \& Strube, 1997; Liversedge, Paterson, \& Pickering, 1998; Rayner, 1998; Rayner \& Duffy, 1986). Total time is the duration of all fixations in a region and indicates overall processing difficulty (Rayner, 1998).

We chose four analysis regions (see Table 1, 'NP1', 'NP2', 'NP3', and 'NP4') motivated by findings of parallelism effects at 'NP3', and 'NP4' in the second conjunct (Knoeferle \& Crocker, 2009, 2010). In addition, I report analyses for the noun phrases of the first clause ('NP1' and 'NP2'): reading times should be longer for marked object-subject than unmarked subject-object clauses (e.g., Knoeferle \& Crocker, 2009, 2010; Schriefers, Friederici, \& Kuhn, 1995; Traxler, Morris, \& Seely, 2002). To explore potential parallelism or conjunction effects post-NP4, I also examined later sentence regions.

The data for NP3 and NP4 summarized by participants (F1) or items (F2) were subjected to repeated-measures Analyses of Variance (ANOVA) with the factors conjunction ('and' vs. 'but'), and parallelism (parallel vs. non-parallel constituent order). I include partial eta square as a measure of effect size (Cohen, 1973). Repeated measures ANOVAs with the factor markedness (marked vs. unmarked first conjunct) examined effects of markedness for NP1 and NP2. List was included as a between-participant variable for the $F 1$ analyses, and item-condition grouping as a between-item variable for the $F 2$ analyses to capture variance resulting from the Latin Square assignment of itemcondition combinations to the four experimental lists (Pollatsek \& Well, 1995). I report the original reading times but $F$-tests were performed on log-transformed data to reduce positive skew. Results are reported as significant if the null hypothesis was rejected at the .05 level in both the participants and items analyses. Complex interactions were followed up with paired-samples $t$-tests for which Bonferroni adjustments ensured an appropriate alpha level of $0.05(0.05 / 2$ since 2 tests were conducted). I report the original $t$-values and the adjusted $p$-values.

\section{Results and discussion}

Participants correctly answered $86.54 \%$ of the questions with a "yes" reply and $87.90 \%$ of the questions with a "no" reply. Missing values and individual data points more than \pm 2 standard deviations from the mean of a participant/item in a condition ( $<4.2 \%$ of the data) were removed.

At NP1, all three measures show reliably longer reading times for marked than unmarked constituent order (Table 2, all F1s \& F2s $>11, \eta^{2} s>0.28$; first pass: $\min F(1,51)=7.48, \quad p<.01 ; \quad$ regression path duration: $\min F(1,50)=7.65, p<.01 ;$ total times: $\min F(1,54)=24.47$, $p<.001)$. At NP2, the same pattern emerged in regression path and total times $\left(F 1 \mathrm{~s} \& F 2 \mathrm{~s}>10.00, \eta^{2} \mathrm{~s}>0.29\right.$; regression path: $\min F(1,46)=14.02$; total times: $\min F(1,50)=8.05)$. At NP3 and NP4, total reading times were shorter for parallel (NP3: $1268.64 \mathrm{~ms} S E=88.14$; NP4: $1117.51 \mathrm{~ms}, S E=73.51)$ than non-parallel (NP3: $1406.61 \mathrm{~ms}, S E=97.13$; NP4: $1273.08 \mathrm{~ms}, S E=78.38)$ constituent order. There was neither a main effect of conjunction nor a reliable interaction of conjunction and parallelism at NP3 and NP4 (see Table 3). Neither the two main effects nor their interaction were reliable for the ensuing region ('wie der Journalist schreibt', $p s>.1$ ).

Analyses of the eye-gaze data confirmed clear parallelism effects in total times at NP3 and NP4, with shorter reading times for parallel than non-parallel constituent order. This corroborates reports of parallelism effects by Knoeferle and Crocker (2009) and together with the existing body of evidence reaffirms that all sorts of linguistic structure can robustly elicit parallel structure facilitation in coordination. The subtly differing time course (parallelism effects appeared in total times but, unlike in Knoeferle and Crocker, not in regression path times at NP4) could result from the greater overall variation in conjunctions, perhaps leading to somewhat less incremental clausal integration. Conjunction meaning ('and' vs. 'but') did not modulate constituent order parallelism effects.

These findings disconfirm predictions by the semantic account (i.e., that conjunction meaning modulates constituent order parallelism effects) and they are compatible with simple priming. Recall that on the semantic account expectations of semantically parallel and contrastive relations elicited by 'and' and 'but' respectively are applied to 
Table 2

Mean reading times in ms (summarized by participants) for each analysis region and condition in Experiment 1 (standard error of the mean in brackets).

\begin{tabular}{|c|c|c|c|}
\hline & First pass time $(S E)$ & Regression-path $(S E)$ & Total time (SE) \\
\hline $\begin{array}{l}\text { NP1 region } \\
\text { unmarked } \\
\text { marked }\end{array}$ & $\begin{array}{l}479.77(22.77) \\
586.06(30.15)\end{array}$ & $\begin{array}{l}665.97(53.96) \\
832.27(59.20)\end{array}$ & $\begin{array}{l}1216.00(101.58) \\
1649.34(137.70)\end{array}$ \\
\hline $\begin{array}{l}\text { NP2 region } \\
\text { unmarked } \\
\text { marked }\end{array}$ & $\begin{array}{l}556.56(30.42) \\
601.43(34.47)\end{array}$ & $\begin{array}{l}702.93(47.86) \\
994.65(72.50)\end{array}$ & $\begin{array}{l}1224.57(98.58) \\
1451.46(97.08)\end{array}$ \\
\hline $\begin{array}{l}\text { NP3 region } \\
\text { 'and', non-parallel } \\
\text { 'and', parallel } \\
\text { 'but', non-parallel } \\
\text { 'but', parallel }\end{array}$ & $\begin{array}{l}554.24(27.38) \\
526.89(29.95) \\
537.72(31.82) \\
530.53(27.15)\end{array}$ & $\begin{array}{l}720.03(34.49) \\
771.48(68.75) \\
790.14(66.99) \\
719.24(74.14)\end{array}$ & $\begin{array}{l}1381.44(93.39) \\
1274.00(88.38) \\
1431.79(117.21) \\
1263.29(94.13)\end{array}$ \\
\hline $\begin{array}{l}\text { NP4 region } \\
\text { 'and', non-parallel } \\
\text { 'and', parallel } \\
\text { 'but', non-parallel } \\
\text { 'but', parallel }\end{array}$ & $\begin{array}{l}520.55(32.72) \\
524.16(27.71) \\
558.02(42.60) \\
537.29(33.91)\end{array}$ & $\begin{array}{l}966.98(103.29) \\
968.99(71.17) \\
1197.80(116.32) \\
958.86(84.67)\end{array}$ & $\begin{array}{l}1195.94(75.09) \\
1108.81(70.32) \\
1350.22(97.50) \\
1126.20(86.36)\end{array}$ \\
\hline
\end{tabular}

Note: For NP1 and NP2, 'markedness' refers to the first clause; for the NP3 and NP4 regions, markedness was a constant.

Table 3

Inferential analyses for Experiment $1\left(d f 1=1, d f 2=28\right.$ for $F 1$ and $F 2$; $d f s$ for $m i n F^{\prime}$ are in brackets after the respective minF' values, $d f 1, d f 2$ ).

\begin{tabular}{|c|c|c|c|c|c|c|c|}
\hline Region & Measure & Factors & $F 1$ & Partial eta squared $\eta^{2}$ & $F 2$ & Partial eta squared $\eta^{2}$ & $\min F^{\prime}$ \\
\hline \multirow{9}{*}{ NP3 } & \multirow[t]{3}{*}{ First pass } & conjunction & 0.05 & 0.00 & 0.14 & 0.01 & \\
\hline & & parallelism & 0.81 & 0.03 & 1.25 & 0.04 & \\
\hline & & $c \times p$ & 0.63 & 0.02 & 1.44 & 0.05 & \\
\hline & \multirow{3}{*}{ Regression path } & conjunction & 0.26 & 0.01 & 0.12 & 0.00 & \\
\hline & & parallelism & 0.65 & 0.02 & 1.34 & 0.05 & \\
\hline & & $\mathrm{c} \times \mathrm{p}$ & 0.95 & 0.03 & 0.15 & 0.01 & \\
\hline & \multirow[t]{3}{*}{ Total times } & conjunction & 0.01 & 0.00 & 0.19 & 0.01 & \\
\hline & & parallelism & $6.65^{*}$ & 0.19 & $9.30^{* *}$ & 0.25 & $3.88^{\#}(1,54)$ \\
\hline & & $\mathrm{c} \times \mathrm{p}$ & 0.31 & 0.01 & 0.01 & 0.00 & \\
\hline \multirow[t]{9}{*}{ NP4 } & \multirow[t]{3}{*}{ First pass } & conjunction & 0.31 & 0.01 & 0.36 & 0.01 & \\
\hline & & parallelism & 0.00 & 0.00 & 1.02 & 0.04 & \\
\hline & & $\mathrm{c} \times \mathrm{p}$ & 0.10 & 0.00 & 0.00 & 0.00 & \\
\hline & \multirow[t]{3}{*}{ Regression path } & conjunction & 2.29 & 0.08 & 0.99 & 0.03 & \\
\hline & & parallelism & 2.77 & 0.09 & 2.29 & 0.08 & \\
\hline & & $\mathrm{c} \times \mathrm{p}$ & 2.32 & 0.08 & 0.86 & 0.03 & \\
\hline & \multirow[t]{3}{*}{ Total times } & conjunction & 1.63 & 0.06 & 2.37 & 0.08 & \\
\hline & & parallelism & $14.69^{* *}$ & 0.34 & $8.70^{* *}$ & 0.24 & $5.46^{*}(1,53)$ \\
\hline & & $\mathrm{c} \times \mathrm{p}$ & 2.02 & 0.07 & 1.21 & 0.04 & \\
\hline
\end{tabular}

Note: The first column marks the word region; columns 2 and 3 index the gaze measure and analysis factors respectively. Columns 4-7 present the $F$-values and values of effect size for the $F 1$ and $F 2$ analyses. Column 8 presents $m i n F^{\prime}$ and $d f s$ for effects that were reliable in the $F 1$ and $F 2$-analyses.

\# $p<.1$.

$p<.05$.

** $p<.01$.

the noun phrases in the second conjunct. Closer inspection shows, however, that participants encountered an adverb and a verb prior to the two noun phrases (see Table 1 , CONJ-ADV-V-NP-NP). The intervening adverb in the second clause ('currently') established a semantic contrast with the corresponding temporal adverb in the first clause (e.g., 'an hour ago'), and could thus satisfy semantically contrastive expectations even before comprehenders encounter the nouns. Perhaps these expectations did not affect constituent order parallelism at the two noun phrases because they had already been satisfied by the preceding adverb and verb.

Experiment 2 addressed this possibility by removing the adverbs, and thus eliminating the temporal contrast they established. I also changed the word order in the two clauses (from main clause coordination to the coordination of sub-ordinate clauses) such that the verb moved to a clause-final position (Table 5). Because of these changes, no other words intervened between the conjunction and the target noun phrases in Experiment 2 ('the tippler' and 'the thug'). If expectations derived from the first conjunct and the conjunction play a role, they should modulate parallelism effects at the two noun phrases in the second conjunct.

In comparison with Experiment 1 (Table 1), the two conjuncts in the sentences from Experiment 2 (Table 5) depended upon a common superordinate verb. When two clauses depend on a common superordinate verb, they belong together in the syntactic analysis; this plausibly strengthens their semantic coherence (see, e.g., 
Percent completions for the completion studies in Experiments 1, 2, and 3 coded for syntactic structure and for semantic similarity with the first conjunct.

\begin{tabular}{|c|c|c|c|c|c|c|}
\hline & \multicolumn{6}{|c|}{ Sentence completions } \\
\hline & \multicolumn{3}{|l|}{ Syntactic coding } & \multicolumn{3}{|c|}{ Semantic coding } \\
\hline & Subject-object & Object-subject & Other & Sem. similar & Sem. contrastive & Other \\
\hline \multicolumn{7}{|c|}{ Completion study $1-\operatorname{Exp} 1(N=12)$} \\
\hline Adv-V-O-S-and-Adv- $V_{-}$ & 90.6 & 4.2 & 5.6 & 57.8 & 22.3 & 19.9 \\
\hline Adv-V-S-O-and-Adv-V_ & 89.5 & 4.2 & 5.6 & 60.1 & 25.5 & 14.3 \\
\hline Adv-V-O-S-but-Adv-V_ & 82.1 & 11.6 & 5.6 & 58.9 & 28.2 & 12.9 \\
\hline \multirow[t]{2}{*}{ Adv-V-S-O-but-Adv-V } & 88.5 & 7.3 & 3.5 & 52.1 & 35.8 & 12.2 \\
\hline & VP-coord. & Object-subject & Other & Sem. similar & Sem. contrastive & Other \\
\hline \multicolumn{7}{|c|}{ Completion study $2-\operatorname{Exp} 2(N=12)$} \\
\hline$\ldots, \mathrm{O}-\mathrm{S}-\mathrm{V}$-and-O & 63.5 & 28.8 & 7.6 & 55.6 & 34.4 & 10.1 \\
\hline$\ldots, \mathrm{S}-\mathrm{O}-\mathrm{V}$-and-O & 73.3 & 13.9 & 12.8 & 46.9 & 37.2 & 16.0 \\
\hline$\ldots, \mathrm{O}-\mathrm{S}-\mathrm{V}-\mathrm{but}-\mathrm{O}$ & 62.5 & 27.1 & 10.4 & 13.2 & 75.3 & 11.5 \\
\hline$\ldots, \mathrm{S}-\mathrm{O}-\mathrm{V}-$ but-O & 73.3 & 22.2 & 4.5 & 7.6 & 82.3 & 10.1 \\
\hline \multicolumn{7}{|c|}{ Completion study $3-\operatorname{Exp} 3(N=12)$} \\
\hline$\ldots, \mathrm{O}-\mathrm{S}-\mathrm{V}$-and-O__ & 58.3 & 33.3 & 8.3 & 46.2 & 41.3 & 12.5 \\
\hline$\ldots, \mathrm{S}-\mathrm{O}-\mathrm{V}$-and-O_ & 86.1 & 6.3 & 7.6 & 49.0 & 35.1 & 16.0 \\
\hline$\ldots, \mathrm{O}-\mathrm{S}-\mathrm{V}$-while-O_ & $1.0^{\mathrm{a}}$ & 84.4 & 14.6 & 25.3 & 55.6 & 19.1 \\
\hline$\ldots, \mathrm{S}-\mathrm{O}-\mathrm{V}-\mathrm{while}-\mathrm{O}$ & $1.0^{\mathrm{a}}$ & 77.1 & 21.9 & 18.4 & 61.5 & 20.1 \\
\hline
\end{tabular}

The tabled percentages for the semantic coding derive from three raters (PK and two linguistically trained undergraduate research assistants). The syntactic coding was performed by PK for Experiment 1, and by all three raters for the syntactic completions in Experiments 2 and 3 (this ensured robust coding for the locally structurally ambiguous sentences in these latter two studies, see the Supplementary materials for details on the coding).

a Coding error: an object-subject order was erroneously coded as a VP-coordination ( $N=3$ each).

Table 5

Example item sentence set for Experiment 2. 'NP1' through 'NP4' indicate the four critical noun phrase regions.

\begin{tabular}{|c|c|}
\hline Condition & Sentences \\
\hline $\begin{array}{l}\text { (a) 'and', parallel / } \\
\text { (b) 'but' parallel }\end{array}$ & $\begin{array}{l}\text { Der Polizist berichtete, dass den Trinker (obj) }\left.\right|_{\mathrm{NP} 1} \text { der Rüpel (subj) }\left.\right|_{\mathrm{NP} 2} \text { verfluchte und / aber den Säufer (obj) }\left.\right|_{\mathrm{NP3}} \text { der Rowdy } \\
\text { (subj) }\left.\right|_{\mathrm{NP4}} \text { erschreckte, was niemanden weiter überraschte. } \\
\text { 'The policeman reported that the drunkard (obj) }\left.\right|_{\mathrm{NP1}} \text { the lout (subj) }\left.\right|_{\mathrm{NP} 2} \text { cursed and / but the tippler (obj) }\left.\right|_{\mathrm{NP3}} \text { the thug (subj) } \\
\left.\right|_{\mathrm{NP4}} \text { frightened, which didn't surprise anybody.' }\end{array}$ \\
\hline $\begin{array}{l}\text { (c) 'and', non-parallel / } \\
\text { (d) 'but', non-parallel }\end{array}$ & $\begin{array}{l}\text { Der Polizist berichtete, dass der Trinker (subj) }\left.\right|_{\mathrm{NP1}} \text { den Rüpel (obj) }\left.\right|_{\mathrm{NP} 2} \text { verfluchte und /aber den Säufer (obj) }\left.\right|_{\mathrm{NP3}} \text { der Rowdy } \\
\text { (subj) }\left.\right|_{\mathrm{NP4}} \text { erschreckte, was niemanden weiter überraschte. } \\
\text { 'The policeman reported that the drunkard (subj) }\left.\right|_{\mathrm{NP1}} \text { the lout (obj) }\left.\right|_{\mathrm{NP2}} \text { cursed and / but the tippler (obj) }\left.\right|_{\mathrm{NP3}} \text { the thug (subj) } \\
\left.\right|_{\mathrm{NP4}} \text { frightened, which didn't surprise anybody.' }\end{array}$ \\
\hline
\end{tabular}

Matthiessen \& Thompson, 1988; but see, Blühdorn, 2008), and might accentuate effects of conjunction meaning on clausal integration. The immediate vicinity of the conjunction and the target noun phrases together with the increased semantic coherence should thus facilitate effects of the conjunction on parallelism effects.

\section{Experiment 2}

\section{Method}

\section{Participants}

A further thirty-two native speakers of German with normal or corrected-to-normal vision received 7.50 euro each for participating in the experiment.

\section{Materials and design}

The 32 sentences were derived from the sentences in Experiment 1 by removing the temporal adverbs and by embedding the original conjoined matrix clauses in indirect speech such that the verb occurred after the noun phrases (see Table 5). The design, procedure, and analysis were the same as for Experiment 1. In a sentence completion study, participants $(N=12)$ completed sentence fragments that included NP3 (see Table 5). The NP3 was included since unlike in Experiment 1 it did not disambiguate the constituent order of the second clause. An object case-marked NP3 could either function as the direct object of the subject noun phrase in the first clause (verb phrase, 'VP'-coordination), or as the grammatical object of another subject noun phrase in the second clause. Completions were coded as 'VP-coordination', 'object-subject', or 'other' (ungrammatical, see the Supplementary materials for more details). Analyses suggested that VP-coordination was overall more frequent than object-subject completions $\left(L R \chi^{2}(\mathrm{subj})=269.24, \quad p<.001 ; \quad L R \chi^{2}(\right.$ item $)=269.24$, $p<.001)$. Markedness of the first clause interacted with the syntactic structure of the completions $\left(L R \chi^{2}\right.$ $($ subj $)=26.88, p<.001 ; L R \chi^{2}$ (item) n.s. by $k$-way effects). Participants produced more VP-coordination completions after subject-object (73.3\%) than object-subject (63\%) constituent order and more object-subject completions after object-subject (28\%) than subject-object order (25\%) in the first conjunct. By contrast, the conjunction did not affect the constituent order of sentence completions 
( $p s>.09$ ), and no three-way interaction of conjunction, the markedness of the first clause, and the syntactic structure of the completions emerged ( $p>.1$ by subjects and n.s. for $k$-way effects by items).

I also coded the completions for similarity with the first conjunct ('similar' vs. 'contrastive' vs. 'ambiguous'). Unlike in Experiment 1, coding only the similarity of thematic role relations did not make sense since NP3 was given and NP4 rarely referred back to the first conjunct. It was possible, however, to code for similarity of the clausal events (e.g., contrastive: 'that the violinist (subj) the singer (obj) praises but the drummer (obj) criticizes'; this was not possible in Experiment 1 since the verb was given). The conjunction $\left(L R \chi^{2}(\mathrm{subj})=285.23, p<.0001 ; L R \chi^{2}(\right.$ item $)=$ $292.25, p<.0001)$ and the markedness of the first clause $\left(L R \chi^{2}(\mathrm{subj})=6.88, \quad p<.01 ; \quad L R \chi^{2}(\right.$ item $\left.)=6.98, \quad p<.01\right)$ affected whether the completion established (vs. didn't establish) a semantic contrast with the event in the first conjunct. 'And'-coordination elicited more semantically similar completions (51.25\%) than 'but'-coordination (10.4\%); 'but'-coordination elicited more semantically contrastive completions (78.8\%) relative to 'and' (35.8\%). Unmarked constituent order elicited somewhat fewer similar completions (27.25) than marked constituent order (34.4), and it elicited subtly more contrastive completions (59.75) than marked constituent order (54.85). To obtain a further measure of the extent to which the completions were semantically similar to the given sentence fragments I translated the core concepts of the completions into English and performed a pair-wise Latent Semantic Analysis (LSA) between the completions and the sentence fragments given to participants. Ensuing ANOVA analyses revealed that the conjunction affected the LSA values (marginal by participants, $F 1(1,11)=3.64, p=.08, \eta^{2}=0.25$; reliable by items: $\left.F 2(1,31)=10.51, p<.01, \eta^{2}=0.25\right)$. Constituent order also affected the LSA values, marginally so by participants and significant by items $(F 1(1,11)=4.4$, $\left.p=.06 ; \eta^{2}=0.29 ; F 2(1,31)=6.41, p<.02 \eta^{2}=0.17\right)$. The interaction of these two factors was marginal by items (by participants: $p>.1 ; F 2(1,31)=4.06, p=.05, \eta^{2}=0.12$ ). There were thus clear effects of the conjunction on the semantics of the completions and some evidence that the syntactic structure affected the semantics of the completions. In line with these findings and with the semantic account, effects of conjunction meaning on parallelism facilitation should emerge during processing of the second conjunct.

\section{Results and discussion}

Participants $(N=32)$ correctly answered $86.14 \%$ and $85.19 \%$ of the questions with a "yes" and "no" reply respectively. Missing values and individual data points more than \pm 2 standard deviations from the mean of a participant/item in a condition ( $<3.9 \%$ of the data) were removed.

For NP1, first pass, regression path and total times were reliably longer for marked than unmarked constituent order (Table 6, F1s $>10, \eta^{2} \mathrm{~s}>0.2, F 2 \mathrm{~s}>9, \eta^{2} \mathrm{~s}>0.2$; first pass: $\min F(1,56)=4.93, p<.05$; regression path duration: $\min F(1,56)=14.40, \quad p<.001$; total times: $\min F(1,53)=$ 11.87, $p<.01)$. At NP2, markedness effects were reliable by items $\left(F 2(1,28)=7.70, p<.05, \eta^{2}>0.2\right)$ and marginal by participants $(F 1(1,28)=4.21, p<.1)$ in regression path times.

At NP3, sentences with und ('and', $540 \mathrm{~ms}, S E=23.02$ ) were read more slowly in first pass times than those for aber ('but', $502 \mathrm{~ms}, S E=17.8$; marginally so by participants and reliably so by items). At NP4, total reading times were shorter for parallel $(1036 \mathrm{~ms}, S E=73.88)$ than non-parallel (1164 $\mathrm{ms}, S E=78.24$ ) constituent order. In addition, reliable parallelism effects (by items) emerged in regression path times. Analyses of total times at NP4 crucially revealed a reliable interaction of conjunction and parallelism (Tables 6 and 7). Paired $t$-tests confirmed the interaction resulted from the presence of parallelism facilitation for 'and' ( $t_{1}=3.26, p<.01, t_{2}=2.61, p<.03$ ), and no evidence for such a difference with 'but' trials $\left(t_{1}<1, t_{2}<1\right)$.

Post-NP4, at the verb, a main effect of conjunction was marginal in first pass $\left(F 1(1,28)=3.23, p=.08, \eta^{2}=0.10\right.$; $\left.F 2(1,28)=3.57, p=.07, \eta^{2}=0.11\right)$, reliable in total times $\left(F 1(1,28)=7.81, p<.01, \eta^{2}=0.22 ; F 2(1,28)=7.81, p<.01\right.$, $\left.\eta^{2}=0.22\right)$, and reliable by items in regression path times $\left(F 2(1,28)=7.82, p<.01, \eta^{2}=0.22\right)$. Reading times were faster for 'and' than for 'but'-coordination (first pass: 338.06, $S E=11.87$ vs. $364.85, S E=16.40$; total times: $653.39 \mathrm{~ms}$, $S E=33.80$ vs. $724.97 \mathrm{~ms}, S E=46.57$ respectively). In addition, there was a main effect of parallelism in the same region for total times $\left(F 1(1,28)=4.76, p<.04, \eta^{2}=0.15\right.$; $\left.F 2(1,28)=2.72, p=.11, \eta^{2}=0.09\right)$. The interaction of parallelism and conjunction was reliable by items in regression path times (a parallelism effect for 'and' and no parallelism effect for 'but': $F 2(1,28)=4.47, p<.05, \eta^{2}=0.14$; first pass and total times, Fs $<1$ ). For the rest of the sentence (was niemanden weiter überraschte, 'which didn't surprise anybody'), the only reliable effect of interest was a main effect of conjunction with shorter total reading times for 'and' than for 'but'-coordination $(F 1(1,28)=13.56, p<.01$, $\eta^{2}=0.33 ; \quad F 2(1,28)=9.08, \quad p<.01, \quad \eta^{2}=0.25 ; \quad$ 'and': 1247.52, $S E=64.29$; 'but': $1366.51 \mathrm{~ms}, S E=70.32$; all other ps > .09).

Analyses of the eye-tracking data replicated significant parallelism facilitation in total times at NP4 and, unlike in Experiment 1, conjunction meaning modulated the parallelism facilitation. Follow-up analyses confirmed no reliable difference between the parallel and non-parallel conditions in total times at NP4 for 'but'-coordination while that difference was significant for 'and'-coordination. This result would not have been predicted by the simple priming account (i.e., with surprisal based on a nonlexicalized PCFG, e.g., Dubey et al., 2009). The semantic interpretation account, by contrast, predicted modulation of parallelism effects for 'but'-coordination. It did not, however, predict the exact pattern of modulation for 'but', viz. virtually identical reading times for the parallel compared with non-parallel conditions. Rather, it had predicted longer reading times for parallel than non-parallel conditions (see also the General Discussion).

The semantic account also received support from clear effects of the conjunction on the semantic similarity of the completions in Experiment 2. Effects of the conjunction further emerged in the gaze pattern from Experiment 2, post-NP4 ('and'-trials were read faster than 'but' trials). 
Table 6

Mean reading times in ms (summarized by participants) for each analysis region and condition in Experiment 2 (standard error of the mean in brackets).

\begin{tabular}{lccc}
\hline & First pass time $(S E)$ & Regression-path $(S E)$ & Total time $(S E)$ \\
\hline $\begin{array}{l}\text { NP1 region } \\
\text { unmarked } \\
\text { marked }\end{array}$ & $425.87(24.51)$ & $529.25(24.92)$ & $1222.71(120.86)$ \\
NP2 region & $508.35(28.25)$ & $698.40(41.25)$ & $1523.06(133.35)$ \\
unmarked & & & \\
marked & $483.01(20.23)$ & $567.84(32.18)$ & $1370.62(144.85)$ \\
NP3 region & $515.92(27.51)$ & $643.40(31.86)$ & $1416.79(118.38)$ \\
'and', non-parallel & & & \\
'and', parallel & $554.00(26.67)$ & $643.58(40.67)$ & $1467.38(125.75)$ \\
'but', non-parallel & $526.11(25.40)$ & $705.06(74.96)$ & $1415.36(124.05)$ \\
'but', parallel & $504.25(20.67)$ & $688.69(56.84)$ & $1412.41(103.20)$ \\
NP4 region & $501.29(24.23)$ & & $1405.89(118.20)$ \\
'and', non-parallel & & & \\
'and', parallel & $405.09(22.24)$ & $669.86(36.23)$ & $1229.47(100.71)$ \\
'but', non-parallel & $381.29(19.97)$ & $634.53(40.88)$ & $967.77(74.22)$ \\
'but', parallel & $427.46(21.88)$ & $717.26(68.96)$ & $1099.11(72.62)$ \\
\hline
\end{tabular}

Table 7

Inferential analyses for Experiment $2\left(d f 1=1 ; d f 2=28\right.$; $d f s$ for $m i n F^{\prime}$ are in brackets after the respective $\min F^{\prime}$ values, $\left.d f 1, d f 2\right)$.

\begin{tabular}{|c|c|c|c|c|c|c|c|}
\hline Region & Measure & & $F 1$ & Partial eta squared $\eta^{2}$ & $F 2$ & Partial eta squared $\eta^{2}$ & $\min F^{\prime}$ \\
\hline \multirow[t]{9}{*}{ NP3 } & \multirow[t]{3}{*}{ First pass } & conjunction & $3.41^{\#}$ & 0.11 & $6.73^{*}$ & 0.19 & \\
\hline & & parallelism & 1.24 & 0.04 & 0.78 & 0.03 & \\
\hline & & $\mathrm{c} \times \mathrm{p}$ & 0.43 & 0.02 & 1.25 & 0.04 & \\
\hline & \multirow[t]{3}{*}{ Regression path } & conjunction & 1.10 & 0.04 & 1.63 & 0.06 & \\
\hline & & parallelism & 0.06 & 0.00 & 1.35 & 0.05 & \\
\hline & & $\mathrm{c} \times \mathrm{p}$ & 0.81 & 0.03 & 0.02 & 0.00 & \\
\hline & \multirow[t]{3}{*}{ Total times } & conjunction & 0.04 & 0.00 & 0.09 & 0.00 & \\
\hline & & parallelism & 2.06 & 0.07 & 0.75 & 0.03 & \\
\hline & & $\mathrm{c} \times \mathrm{p}$ & 0.09 & 0.00 & 0.46 & 0.02 & \\
\hline \multirow[t]{9}{*}{ NP4 } & \multirow[t]{3}{*}{ First pass } & conjunction & 2.30 & 0.08 & 1.93 & 0.06 & \\
\hline & & parallelism & 0.96 & 0.03 & 0.84 & 0.03 & \\
\hline & & $\mathrm{c} \times \mathrm{p}$ & 0.20 & 0.01 & 0.09 & 0.00 & \\
\hline & \multirow[t]{3}{*}{ Regression path } & conjunction & 1.86 & 0.06 & 0.07 & 0.00 & \\
\hline & & parallelism & 0.55 & 0.02 & $4.48^{*}$ & 0.14 & \\
\hline & & $\mathrm{c} \times \mathrm{p}$ & 0.29 & 0.01 & 1.38 & 0.05 & \\
\hline & \multirow[t]{3}{*}{ Total times } & conjunction & 1.46 & 0.05 & 0.42 & 0.02 & \\
\hline & & parallelism & $12.28^{* *}$ & 0.31 & $8.05^{* *}$ & 0.22 & $4.86(1,54)$ \\
\hline & & $\mathrm{c} \times \mathrm{p}$ & 7.75 & 0.22 & 6.80 & 0.20 & $3.62^{\#}(1,56)$ \\
\hline
\end{tabular}

Note: The first column marks the word region; columns 2 and 3 index the gaze measure and analysis factors respectively. Columns 4-7 present the $F$-values and values of effect size. Column 8 presents $\min ^{\prime}$ and $d f$ s for effects that were reliable in the $F 1$ and $F 2$-analyses.

\# $p<.1$.

${ }^{*} p<.05$.

${ }^{* *} p<.01$.

These effects could reflect the higher frequency of occurrence of 'and' than 'but'-coordination. Parallelism and conjunction effects as well as their interaction (by items) were ongoing after NP4; these effects likely reflect ongoing clausal integration and corroborate the semantic account. Compared with Experiment 1, the clear effects of conjunction meaning on the semantic integration of the coordinands could result from the absence (vs. presence) of the temporal adverbs and (pre-NP) verb, and/or from the structural position of the coordinands (main clause vs. complement clauses). Future research will examine the relative contribution of these factors to the observed effects.

Despite good support for the semantic account, consider an alternative, 'garden-path' account: For the non-parallel conditions, participants could expect a transitive verb after the NP3 instead of another noun phrase, since VP-coordination is possible at this point. If this is the case, then participants should experience a gardenpath in the non-parallel conditions when they encounter NP4. If the preference for VP coordination were stronger in the non-parallel than parallel conditions, and stronger for 'and' than for 'but, this would lead to different amounts of revision at the NP4. Such differences in the revision of a garden-path, if present, could accommodate the increased reading times at NP4 for non-parallel relative to parallel constituent order; the garden-path account would also predict the longer reading times for non-parallel than parallel constituent order in 'and'-coordination and the reduced difference in 'but'-coordination. 
One indication of more revision processes for 'and' than for 'but' coordination comes from the reading time increases for 'and' relative to 'but' trials at NP3 (presumably revision is elicited through parafoveal preview). However, the revision was short-lived (NP3) and the main effect of conjunction did not extend to NP4, which is when conjunction began to modulate parallelism effects. In the completion data, VP-coordination completions were further equally frequent for (non-parallel vs. parallel) 'but' and 'and'-coordination. The garden-path account thus cannot accommodate differences in constituent order parallelism facilitation for 'and' vs. 'but'-coordination at and post NP4.

As discussed, 'but' imposes semantic constraints on the coordinands. At the same time, coordinating conjunctions also impose syntactic constraints in that an element may not be extracted from just one conjunct (e.g., Ross, 1967, in Marta leads the group and drives a beamer, moving just one coordinand out of the coordination is not possible, *What did Marta lead and drive the beamer?, whereby * indicates a non-felicitous sentence); by contrast, extracting similar elements from both conjuncts is acceptable (but see Kehler, 1996). For our materials, extraction of just one noun from a conjunct is also not possible with coordinating conjunctions (e.g., for the sentences in Table 5: *Wer verfluchte den Trinker und den Säufer der Rowdy erschreckte?).

By contrast, German während ('while') is a subordinating conjunction, which does not necessarily link morphosyntactically similar constituents and which is "structurally asymmetric" (Blühdorn, 2008, p. 6; see, Pasch et al., 2003). For während, extraction of one noun is accordingly possible (Wer verfluchte den Trinker während den Säufer der Rowdy erschreckte?).

Experiment 3 examined the extent to which parallelism effects are modulated by während. Während permits contrastive relations (während, 'while'; see Spenader \& Lobanova, 2009) but is not coordinating and fully disambiguates the syntactic structure of the second conjunct, enforcing an object-first interpretation at NP3. Such immediate disambiguation could enhance any priming effects of object-subject constituent order from the first to the second conjunct and the reduced syntactic constraints of the two conjuncts could reduce effects of the conjunction. The simple priming account would predict clear priming effects for both undcoordination and während-subordination, a finding which would confirm claims that a coordinate structure environment is not essential for procuring parallelism facilitation (Sturt et al., 2010). On the compositional semantic interpretation account, by contrast, parallelism effects should appear on the two noun phrases for 'and'-coordination only. Während should lead to reversed parallelism effects following the semantic account or to a null effect if we replicate the results for 'but'-coordination in Experiment 2.

\section{Experiment 3}

\section{Method}

\section{Participants}

Sixty-four further participants from the same population received 7.50 euros for participation.
Materials, design, procedure ${ }^{5}$ and Analysis

Experiment 3 was identical to Experiment 2 except for replacing aber ('but', Table 5) in the sentence stimuli with während ('while'). A sentence completion study with the materials for Experiment 3 presented fragments up to and including NP3. Both the structure of the first clause $\left(L R \chi^{2}(\mathrm{subj})=74.77, \quad p<.001 ; \quad L R \chi^{2}(\right.$ item $)=21.72 .11$, $p<.001)$ and the conjunction $\left(L R \chi^{2}(\mathrm{subj})=883.40\right.$, $p<.0001 ; L R \chi^{2}$ (item) $\left.=824.56, p<.0001\right)$ affected the syntactic structure of the completion, likely because während disambiguated the structure of the second conjunct. The three-way interaction of markedness, conjunction and the syntactic structure of the completions was not significant ( $k$-way effects $n$.s.). There was a high percentage of VP-coordination completions with 'and' (72.2); for 'while', VP-coordination completion is not possible and was at $1 \%$ (the 1\% came from an error in coding a completion as VP-coordination when it was not, $N=3$ ). By contrast, more object-subject completions emerged with 'while' than 'and' (81.75\% vs. 19.8\%). In addition, object-subject completions were more frequent after object-subject (vs. subject-object) order ( $58.85 \%$ vs. $41.7 \%$ ), and VP-coordination was more frequent after subject-object (vs. objectsubject) order in the first conjunct (43.55\% vs. $29.65 \%$ ).

The semantics (similar vs. contrastive) of the completions depended upon the conjunction $\left(L R \chi^{2}(\mathrm{subj})=87.79\right.$, $p<.001 ; L R \chi^{2}($ item $\left.)=99.36, p<.001\right)$ but not the markedness of the first clause. To gain a further measure of the degree to which the completions were semantically similar to the given sentence fragments I translated the core concepts of the completions into English and performed a pair-wise Latent Semantic Analysis (LSA) on the completions produced by the 12 participants. The mean LSA values were 0.21 (non-parallel 'and'), 0.29 (parallel 'and'), 0.21 (non-parallel 'while'), and 0.23 (parallel 'while'). Analyses confirmed marginal effects of conjunction $(F 1(1,11)=4.50, p=.06 ; F 2(1,31)=1.76, p=.2)$ and reliable effects of markedness on the LSA ratings $(F 1(1,11)=4.90$, $p<.05 ; F 2(1,31)=6.28, p<.02)$ in the absence of a reliable interaction. The conjunction effects on both the semantic similarity of the completions and the LSA ratings replicate the results from the completion study in Experiment 2. Based on these results and in line with the semantic account we should see clear parallelism effects for 'and' coordination and reduced effects for 'while'-coordination.

\section{Results and discussion}

Participants $(N=64)$ correctly answered $86.79 \%$ of the filler questions with a "yes"- and "no"-reply. Individual data points that were more than \pm 2 standard deviations from the mean of a participant/item in a condition as well

\footnotetext{
5 The procedure was identical to Experiment 1 for the first 32 participants and had only minor changes for the second 32 participants in Experiment 3. This was unavoidable because PK moved to a new university, and more data collection was necessary. For the second 32 participants an Eyelink II eye tracker (desktop mount; setup with chinrest) monitored eye gaze at $250 \mathrm{~Hz}$. The display screen was a 22-inch instead of 21-inch monitor. Adjustment of vertical gaze position, previously executed by a perl script, was performed in Data Viewer by a student who was blind to the manipulations.
} 
as missing values ( $<3.25 \%$ of the eye-tracking data) were removed.

Reading times were reliably longer for marked objectsubject than unmarked subject-object order both at the NP1 region (in all three measures, $F 1 \mathrm{~s}$ and $F 2 \mathrm{~s}>16.00$, $\eta^{2} \mathrm{~s}>0.2$; first pass: $\min F(1,120)=8.40, p<.01$; regression path time: $\min F(1,120)=18.13, p<.001$; total times: $\min F(1,120)=35.48, p<.001)$ and at the NP2 region (in regression path and total times, see Table $8, F 1 \mathrm{~s}$ and $F 2 \mathrm{~s}>16.00, \quad \eta^{2} \mathrm{~s}>0.2$; regression path time: $\min F(1,120)=8.78, \quad p<.01$; total times: $\min F(1,118)=$ $10.48, p<.01)$.

Analyses for the NP3 region revealed longer first pass ('and': $510 \mathrm{~ms}, S E=18.04$ vs. 'while': $471 \mathrm{~ms}, S E=20.00$ ), regression path ('and': $625 \mathrm{~ms}, S E=36.21$ vs. 'while': $557 \mathrm{~ms}, S E=24.03$ ), and total times ('and': $1084 \mathrm{~ms}$, $S E=57.13$ vs. 'while': $966 \mathrm{~ms}, S E=48.27)$ for 'and' than for 'while' (Table 9). In addition, there was a reliable effect of parallelism in regression path times by participants at NP3. Separate follow-up $t$-tests for 'and' and 'while' coordination revealed no reliable parallelism effects ( $p s>.1$ ). For the NP4 region, main effects of parallelism were only reliable in the analysis by items (in regression path and total times). Analyses confirmed, however, interactions between parallelism and conjunction that were reliable by items in first pass, by participants in regression path times, and fully reliable in the analyses of total times (Table 9). The significant total-time interaction resulted from parallelism facilitation for 'and'-coordination (marginal by participants: $t_{1}=2.12, p=.08$, and significant by items: $t_{2}=2.58$, $p<.03)$ and its reduction for 'while'-subordination $(t s<|1|)$.

There were no reliable effects of the manipulated variables at the post-NP4 verb. For the rest of the sentence ('which didn't surprise anybody'), effects of conjunction were marginal in first pass $(F 1(1,60)=3.38, p=.07$, $\left.\eta^{2}=0.05 ; F 2(1,60)=3.60, p=.06, \eta^{2}=0.06\right)$ and total times $\left(F 1(1,60)=3.22, p=.08, \eta^{2}=0.05 ; F 2(1,60)=4.13, p<.05\right.$, $\eta^{2}=0.06$ ) with faster reading times for 'and' (first pass: $725 \mathrm{~ms}, S E=28.83$; total times: $1082.26 \mathrm{~ms}, S E=45.73$ ) than for 'while' (first pass: $767 \mathrm{~ms} S E=31.82$; total times:
$1138.56 \mathrm{~ms}, S E=50.81)$. There was further a marginal interaction of conjunction and parallelism in total times $\left(F 1(1,60)=3.14, p=.08, \eta^{2}=0.05 ; F 2(1,60)=3.21, p<.08\right.$, $\left.\eta^{2}=0.05\right)$. However, follow-up analyses revealed no significant difference for parallel compared with non-parallel conditions ( $p s>.1$ ).

Analyses of the eye-tracking data replicated parallelism facilitation but its time course was somewhat earlier and more variable (in regression path times at NP3 by participants and at NP4 by items; in total times at NP4 by items). The effects in regression path at NP3 could reflect parallelism effects for 'while' due to its immediate structural disambiguation (see the smaller standard errors in Table 8 for 'while' relative to Table 6 'but'). Follow-up analyses, however, confirmed separate parallelism effects neither for the 'and' nor for the 'while' conditions at NP3.

Crucially, conjunction meaning modulated parallelism facilitation in total times at NP4, thus replicating the results from Experiment 2. The parallel and non-parallel conditions for 'while'-coordination didn't differ in total times at NP4; however, they differed reliably by items and marginally by participants for 'and'-coordination. The gaze-pattern analyses at NP4 thus provide good support for the semantic interpretation account. Consider the possibility of a garden-path account for the total times at NP4: In the sentence completion study 'while' trials elicited $81 \%$ of object-subject completions. This suggests that 'while' disambiguated the sentence structure at NP3; for 'and', however, participants expected a VP-coordination at NP3. Longer reading times for 'and' than 'while' trials at NP3 suggest that participants revised their expectation of a VP-coordination, perhaps through parafoveal preview of NP4. Regression path times at NP4 were also increased for 'and' relative to 'while' trials. Thus, for reading times at NP3 and regression path times at NP4 a garden-path account of the data cannot be excluded. Most importantly however, a garden-path account cannot accommodate the results pattern from Experiments 2 and 3 together since the completion data from Experiment 2 show similar VPcoordination preferences for 'and' and 'but'-coordination.

Table 8

Mean reading times in ms (summarized by participants) for each analysis region and condition in Experiment 3 (standard error of the mean in brackets)

\begin{tabular}{|c|c|c|c|}
\hline & First pass time $(S E)$ & Regression-path (SE) & Total time (SE) \\
\hline \multicolumn{4}{|l|}{ NP1 region } \\
\hline unmarked & $450.76(16.73)$ & $559.93(23.00)$ & $1028.20(59.43)$ \\
\hline marked & $546.51(25.52)$ & $726.28(34.05)$ & 1359.75 (71.89) \\
\hline \multicolumn{4}{|l|}{ NP2 region } \\
\hline unmarked & $497.29(23.26)$ & $557.13(30.42)$ & $1118.45(74.56)$ \\
\hline marked & $512.36(22.48)$ & $667.71(34.67)$ & $1276.19(72.34)$ \\
\hline \multicolumn{4}{|l|}{ NP3 region } \\
\hline 'and', non-parallel & $500.30(18.33)$ & $630.18(35.22)$ & $1096.32(64.80)$ \\
\hline ‘and', parallel & $519.96(24.54)$ & $621.59(48.41)$ & $1072.22(56.67)$ \\
\hline 'while, non-parallel & 481.36 (22.39) & $577.52(26.53)$ & $996.09(54.81)$ \\
\hline 'while, parallel & $461.75(21.64)$ & $537.65(28.73)$ & $936.08(49.85)$ \\
\hline \multicolumn{4}{|l|}{ NP4 region } \\
\hline 'and', non-parallel & $437.25(17.42)$ & $752.16(77.63)$ & 984.57 (64.17) \\
\hline ‘and', parallel & $414.49(17.01)$ & $626.11(53.05)$ & $875.16(50.05)$ \\
\hline 'while', non-parallel & $409.09(18.14)$ & $589.72(39.14)$ & $917.85(54.14)$ \\
\hline ‘while', parallel & $418.09(17.70)$ & $585.33(35.72)$ & $931.49(51.58)$ \\
\hline
\end{tabular}


Table 9

Inferential analyses for Experiment $3\left(d f 1=1 ; d f 2=60\right.$ for $F 1$ and $F 2 ; d f s$ for $\min F^{\prime}$ are in brackets after the respective $\min F^{\prime}$ values, $d f 1, d f 2$ ).

\begin{tabular}{|c|c|c|c|c|c|c|c|}
\hline Region & Measure & & $F 1$ & Partial eta squared $\eta^{2}$ & $F 2$ & Partial eta squared $\eta^{2}$ & $\min F^{\prime}$ \\
\hline \multirow[t]{9}{*}{ NP3 } & \multirow[t]{3}{*}{ First pass } & conjunction & $9.33^{* * *}$ & 0.14 & 2.47 & .04 & \\
\hline & & parallelism & .21 & .00 & .23 & .00 & \\
\hline & & $\mathrm{c} \times \mathrm{p}$ & 1.75 & .03 & .74 & .01 & \\
\hline & \multirow[t]{3}{*}{ Regression path } & conjunction & $4.89^{*}$ & .08 & .46 & .01 & \\
\hline & & parallelism & $4.83^{*}$ & .08 & .50 & .01 & \\
\hline & & $\mathrm{c} \times \mathrm{p}$ & .58 & .01 & 1.96 & .03 & \\
\hline & \multirow[t]{3}{*}{ Total times } & conjunction & $12.60^{* * *}$ & .17 & $8.38^{* * *}$ & .12 & $5.03^{*}(1,115)$ \\
\hline & & parallelism & 1.00 & .02 & 1.16 & .02 & \\
\hline & & $\mathrm{c} \times \mathrm{p}$ & .81 & .01 & .00 & .00 & \\
\hline \multirow[t]{9}{*}{ NP4 } & \multirow[t]{3}{*}{ First pass } & conjunction & 1.41 & .02 & .02 & .00 & \\
\hline & & parallelism & .37 & .01 & .31 & .01 & \\
\hline & & $\mathrm{c} \times \mathrm{p}$ & 2.77 & .04 & $5.37^{*}$ & .09 & \\
\hline & \multirow[t]{3}{*}{ Regression path } & conjunction & 2.47 & .04 & 3.16 $^{\#}$ & .05 & \\
\hline & & parallelism & 2.64 & .04 & $5.22^{*}$ & .08 & \\
\hline & & $\mathrm{c} \times \mathrm{p}$ & $\mathbf{3 . 5 8 ^ { \# }}$ & .06 & 1.89 & .03 & \\
\hline & \multirow[t]{3}{*}{ Total times } & conjunction & .11 & .00 & 1.07 & .02 & \\
\hline & & parallelism & 1.34 & .02 & $2.97^{\#}$ & 0.05 & \\
\hline & & $\mathrm{c} \times \mathrm{p}$ & $4.38^{*}$ & .07 & $6.21^{*}$ & 0.09 & $2.75(1,117)$ \\
\hline
\end{tabular}

Note: The first column marks the word region; columns 2 and 3 index the gaze measure and analysis factors respectively. Columns $4-7$ present the $F$-values and values of effect size. Column 8 presents $m i n F^{\prime}$ and $d f$ for effects that were reliable in the $F 1$ and $F 2$-analyses.

${ }^{\#} p<.1$.

* $p<.05$.

** $p<.01$.

\section{General discussion}

Three eye-tracking experiments assessed to which extent linguistic context can modulate parallelism facilitation. While simple priming predicts parallelism effects are insensitive to properties of the conjunction, the semantic interpretation account predicts that conjunction meaning can modulate them. The experiments accordingly manipulated within subjects (a) clausal constituent order parallelism (whether two noun phrases in a first clause did vs. did not parallel the constituent order of two noun phrases in a second, conjoined, clause); and (b) the conjunction that linked the two clauses (und, 'and' vs. aber, 'but'; und vs. während 'while'). Going beyond the predictions of either account, we further varied across experiments whether the semantic expectations elicited by 'but' and 'while' were violated through either the manipulated noun phrases or other sentence constituents, and whether syntactic dependence reinforced or did not reinforce clausal coherence.

The eye-tracking results from Experiment 1 (mainclause coordination) showed no evidence that parallelism effects in total times at NP3 and NP4 were reduced for 'but'-coordination. This result was in agreement with the absence of any clear effect of the conjunction on either the constituent order or the semantic meaning of the sentence completions in Experiment 1.

By contrast, for Experiments 2 and 3, when the two conjuncts depended from a common superordinate clause, the conjunction affected the semantic similarity of the completions with the first conjunct. Both the conjunction (Experiment 3) and the markedness of the first clause (Experiments 2 and 3 ) affected the syntactic structure of the completions. The completion data support the view that processing the first conjunct, the conjunction, and NP3 can elicit semantic and syntactic expectations that could then modulate constituent order parallelism effects in the second clause. Analyses of the eye-tracking data from Experiments 2 and 3 (coordination of subordinate clauses) revealed that conjunction meaning can modulate parallelism facilitation incrementally. For 'and' (but not 'but'/'while')-coordination, parallelism effects appeared in total times at NP4, at a point when the thematic role relations and the verb in both conjuncts, as well as the conjunction were known and could jointly modulate parallelism facilitation. For 'but' and 'while' sentences, by contrast, reading times were highly similar for parallel and non-parallel constituent order.

\section{Accounting for the effects of conjunction}

A simple priming model based on a probabilistic context free grammar (PCFG) probability model with non-lexicalized rules could accommodate the results from Experiment 1 . When an object-subject rule was recently employed, its higher activation facilitates its re-use during processing of the second conjunct, and the associated surprisal and processing cost are lower than when the objectsubject rule has not recently been employed. This model cannot, however, accommodate the reduced parallelism effects for 'but' and 'while' relative to 'and'-coordination in Experiments 2 and 3.

By contrast, the semantic interpretation account predicts that conjunction meaning can modulate constituent order parallelism facilitation, but it would have predicted a different eye-gaze pattern than the one observed. On that account, 'and' and 'but' trigger expectations of parallel and non-parallel structures respectively at all linguistic levels (phonological, syntactic, and semantic). Non-parallel structures are assigned an increased likelihood of re-occurring following 'but', eliciting lower surprisal and reading times 
when the second conjunct confirms that expectation. If this were indeed the case, then we should have seen a reversal of parallelism facilitation with 'but' and 'while' (faster reading times for non-parallel than parallel structure), but this is not what the analyses revealed. Rather, reading times with 'but' and 'while' were the same for both levels of the parallelism factor while 'and' elicited faster reading times for parallel than non-parallel sentences.

Finally, neither of these two accounts predicted the observed between-experiment variation (Experiment 1 vs. Experiments 2 and 3). To accommodate the results from all three experiments, we need to make further assumptions about compositional interpretation involving the first conjunct, the conjunction, and the second conjunct. One such assumption is that conjunction meaning seems to modulate parallelism facilitation only when the contrast established by the conjunction applies to the (parallel or non-parallel) noun phrase constituents in the second clause. This was the case in Experiments 2 and 3, where the target noun phrases were both adjacent to the conjunction and the only contrasting clausal elements. By contrast, in Experiment 1, the temporal adverb and verb of the second conjunct contrasted with the adverb and verb in the first clause. Since the adverb and verb were moreover adjacent to the conjunction and separated the conjunction from the two target noun phrases, comprehenders could satisfy any expectations of semantic contrast before processing the target noun phrases in the second conjunct. It is possible that, once satisfied, contrastive expectations no longer affected downstream sentence constituents (i.e., the target noun phrases). A further reason for the absence of conjunction effects in Experiment 1, and their presence in Experiments 2 and 3, could relate to sentence structure differences. The coordination of sub-ordinate clauses in Experiments 2 and 3 (compared with main clause coordination in Experiment 1) likely increased clausal coherence and could have enhanced effects of the conjunction. The semantic account together with either (or both) of these two additional factors can accommodate the absence of clear effects of the conjunction on parallelism facilitation in Experiment 1 and its presence in Experiments 2 and 3.

To the extent that clausal coherence alone is the key factor, we should replicate effects of the conjunction on parallelism facilitation even when we insert the temporally contrastive adverbs in sub-ordinate clause coordination (e.g., Der Mann sagt, dass gerade den Fechter der Gegner besiegt und/aber gestern...). If, however, temporal contrast alone is the deciding factor in the differences between Experiments 1 and 2, then we should see conjunction effects in Experiment 1 when we remove the temporal adverbs and position the verb in between the two noun phrases (e.g., Den Fechter besiegt der Gegner und/ aber... 'The fencer (obj) overwhelms the opponent and/ but ...').

An account that can accommodate the present findings must also explain why contrastive conjunctions did not reverse the parallelism effects but merely eliminate them. The completion data can speak to this issue. Sentence fragments in object-subject order elicited more object-subject than subject-object completions (in both Experiments 2 and 3) and at the same time the conjunction modulated the semantic similarity (Experiments 2 and 3 ). This suggests that both constituent order priming and compositional semantic interpretation play a role in procuring the observed facilitation. The eye-tracking data suggest further that they both apply at the same time, at least for the present clause-level parallelism effects, since the observed main effects of parallelism and their interaction with the conjunction emerged in the same measure and at the same word region.

\section{Alternative versions of a priming account}

Consider next, whether alternative instantiations of the priming account could alone accommodate the present results. Priming can operate at multiple levels (e.g., semantic priming: Meyer \& Schvanefeldt, 1971; structural priming: Pickering \& Garrod, 2004; Schenkein, 1980; Weiner \& Labov, 1983, see Pickering \& Ferreira, 2008 for a review), and could thus occur for both constituent order and semantic structure in our sentences. When constituent order is parallel (vs. non-parallel) in our materials, the thematic role relations in the two clauses are also parallel (vs. non-parallel). It is likely that processing benefits from repetition at both of these linguistic levels. However, parallelism effects for 'and' and 'but' coordination would be identical under this account since the repetition of syntactic structure and semantic representations alone (without the effects of the conjunction) would not lead to differential parallelism facilitation for 'and' compared with 'but' coordination.

An alternative lexicalized priming account, discussed in Knoeferle and Crocker (2009), allows conjunction meaning to affect the probability of constituent order rules. For instance, if comprehenders process a first conjunct in object-subject order, that rule would be more highly activated than when it has not recently been active. The conjunction 'and' should boost expectations of the same constituent order. By contrast, but' would boost the activation of non-parallel constituent order. Thus, on the modified priming account, the activation of a constituent order rule would be conditional upon conjunction meaning. This would predict the observed modulation of parallelism facilitation in the reading times through the conjunction. However, in the completion studies, people should have produced more syntactically parallel completions following 'and' than 'but', which was not the case. Instead, the conjunction meaning affected the semantic similarity of the completions. Thus, a view on which the conjunction modulates constituent order parallelism alone does not best accommodate the overall pattern of results.

A lexicalized priming account that incorporates not only the conjunction and constituent order but also conjunct meaning, can accommodate the findings from Experiments 2 and 3 (although one may ask whether it is appropriate to conceptualize the interaction of these three factors as 'priming' rather than compositional processing). The conjunction affected the semantic similarity of the completions in Experiments 2 and 3 and it modulated parallelism effects during reading. In addition, an objectsubject constituent order in the first conjunct primed more 
similar object-subject than subject-object completions. The pattern for the completion and eye-tracking studies together thus implicates both constituent order structure and the semantic context in the observed parallelism effects.

Together (a) the modulation of incremental parallelism effects by the conjunction; (b) the modulation of the semantic similarity of the completions in Experiments 2 and 3 by the conjunction; and (c) the between-experiment context differences, require an account that implicates not only constituent order structure but also the surrounding syntactic and semantic context in parallelism facilitation.

\section{Acknowledgments}

This research was funded by grant CR 135/1-2 awarded to Matthew W. Crocker by the German Research Council (Deutsche Forschungsgemeinschaft), by the Cognitive Interaction Technology Excellence Center (DFG). I am grateful to Matthew Crocker for his support in conducting the present research. I also thank Jens Apel, Emilia Ellsiepen, Lily Kornbluth, Dato Abashidze, Kristin Kleinehagenbrock, Clara Matheus, and Anna-Lena Zurmühlen for assistance with data collection, and three anonymous reviewers for their helpful comments.

\section{Appendix A}

Example stimuli for Experiment 1. The sentences are shown in one version of the conditions, with non-parallel constituent order (subject-object-und-object-subject) in und ('and')-coordination.

1. Gerade eben verfluchte der Trinker den Rüpel und in diesem Moment erschreckt den Säufer der Rowdy, so berichtet der Polizist.

2. Vorhin attackierte der Skinhead den Sträfling und in diesem Augenblick verprügelt den Raufbold der Häftling, wie der Aufseher beobachtet.

3. Gestern begleitete der Sportlehrer den Wettläufer aber heute ermuntert den Radprofi der Rennfahrer, und das alles vor dem Publikum.

4. Soeben traf der Förderer den Bildhauer aber nun grüßt den Edelmann der Hofmaler, das erzählt der Dienstbote.

5. Letzte Woche tadelte der Bischof den Herrscher und diese Woche kritisiert den Dekan der Kanzler, und beides vor allen Leuten.

6. Vor einer Stunde bluffte der Sheriff den Gauner und gerade überlistet den Gendarm der Räuber, und beides passierte zum wiederholten Male.

7. Vorhin bedrohte der Bandenchef den Raubmörder aber jetzt bedrängt den Anführer der Bösewicht, so sagt der Augenzeuge.

8. Gestern rühmte der Gastwirt den Winzer aber heute würdigt den Chefkoch der Gourmet, und das alles mitten im Restaurant.

9. Vor ein paar Minuten lobte der Geiger den Sänger und in diesem Augenblick preist den Trommler der Dichter, wie der Zuschauer hört.
10. Gestern foppte der Gärtner den Pförtner und heute verspottet den Tischler der Butler, sehr zur Empörung des Hausherrn.

11. Vorhin betrachtete der Kunstreiter den Ringkämpfer aber in diesem Augenblick beobachtet den Seiltänzer der Muskelprotz, und das alles kurz vor der Vorstellung.

12. Letzte Woche begutachtete der Rocksänger den Schlagzeuger aber diese Woche bewertet den Startenor der Keyboarder, so steht es in der Zeitung.

13. Vor ein paar Minuten bemerkte der Sporttaucher den Brustschwimmer und in diesem Moment sichtet den Turmspringer der Sprintkrauler, und beides mitten im Schwimmbad.

14. Vor kurzem erspähte der Reiseleiter den Abenteurer und nun erblickt den Fremdenführer der Großwildjäger, und all dies auf der Safari.

15. Soeben konsultierte der Wagenlenker den Autoschlosser aber bereits seit einer Stunde sucht den Fahrzeughalter der Werkstattleiter, wie das Kind bemerkt.

16. Vor einer Stunde neckte der Bäcker den Händler aber jetzt betrügt den Müller der Käufer, sehr zum Erstaunen des Spaziergängers.

17. Gestern tröstete der Penner den Bastard und heute bemitleidet den Bettler der Krüppel, das plaudert der Sozialarbeiter aus.

18. Letzte Woche unterstützte der Kneipenwirt den Meisterkoch und diese Woche vertritt den Barkeeper der Weinkenner, und all dies in der Hochsaison.

19. Gerade eben rief der Bauer den Helfer aber jetzt holt den Farmer den Cowboy, wie die Urlauberin erfährt.

20. Vor kurzem bestach der Staatsdiener den Werksleiter aber bereits seit einer Stunde umschmeichelt den Amtsträger der Firmenboss, das verrät der Angestellte.

21. Gerade eben unterwies der Techniker den Handwerker und bereits seit einer Stunde instruiert den Anstreicher der Arbeiter, sehr zum Wohlwollen des Bauherrn.

22. Vor einer Stunde bezwang der Fechter den Gegner und gerade besiegt den Ringer der Erzfeind, wie der Journalist schreibt.

23. Vor ein paar Minuten informierte der Ausbilder den Springreiter aber in diesem Moment benachrichtigt den Manager der Wettläufer, und das alles direkt nach dem Turnier.

24. Letzte Woche beriet der Priester den Hausarzt aber diese Woche belehrt den Pater der Heiler, und all dies nicht zum ersten Mal.

25. Vorhin verabschiedete der Kaiser den Herzog und jetzt besucht den König der Baron, wie der Schreiber mitteilt.

26. Soeben schikanierte der Marktschreier den Obsthändler und gerade übervorteilte den Einkäufer der Viehzüchter, sehr zum Erzürnen der Hausfrau.

27. Vor kurzem beleidigte der Kapitän den General aber nun beschimpft den Millionär der Offizier, und beides kam schon öfter vor. 
28. Vor kurzem umarmte der Bruder den Vetter aber in diesem Augenblick drückte den Vater der Onkel, sehr zur Freude des Familienoberhauptes.

29. Vor einer Stunde sah der Nachtportier den Landstreicher und gerade entdeckt den Raumpfleger der Einbrecher, und beides nach Schließung der Bank.

30. Vor ein paar Minuten verriet der Verbrecher den Kontaktmann und in diesem Moment verpfeift den Betrüger der Komplize, sehr zur Zufriedenheit des Kommissars.

31. Soeben hänselte der Bengel den Flegel aber bereits seit einer Stunde narrt den Racker der Lümmel, wie man sich vorstellen kann.

32. Gerade eben erkannte der Rektor den Schüler aber nun begrüßt den Lehrer der Prüfling, und beides im Treppenhaus.

Example stimuli for Experiments 2 and 3. The sentences are shown in one version of the conditions, with non-parallel constituent order (subject-object-und-object-subject) in und ('and')-coordination.

1. Der Polizist berichtete, dass der Trinker den Rüpel verfluchte und den Säufer der Rowdy erschreckte, was niemanden weiter überraschte.

2. Der Aufseher meldet, dass der Skinhead den Sträfling attackiert und den Raufbold der Häftling verprügelt, was niemanden weiter verwundert.

3. Der Reporter kommentiert, dass der Sportlehrer den Wettläufer begleitet und den Radprofi der Rennfahrer ermuntert, was ganz plausibel erscheint.

4. Der Dienstbote erzählt, dass der Förderer den Bildhauer trifft und den Edelmann der Hofmaler grüßt, wobei gute Laune spürbar ist.

5. Alle Leute haben gesehen, dass der Bischof den Herrscher tadelte und den Dekan der Kanzler kritisierte, wobei die Atmosphäre angespannt war.

6. Es passierte zum wiederholten Male, dass der Sheriff den Gauner bluffte und den Gendarm der Räuber überlistete, obwohl damit gerechnet wurde.

7. Der Augenzeuge bestätigt, dass der Bandenchef den Raubmörder bedroht und den Anführer der Bösewicht bedrängt, obwohl jeder es sieht.

8. Es geschah mitten im Restaurant, dass der Gastwirt den Winzer rühmte und den Chefkoch der Gourmet würdigte, obwohl große Hektik herrschte.

9. Der Zuschauer hört, dass der Geiger den Sänger lobt und den Trommler der Dichter preist, wie das nur selten vorkommt.

10. Der Hausherr ist sehr empört, dass der Gärtner den Pförtner foppt und den Tischler der Butler verspottet, wobei alles ganz harmlos verläuft.

11. Es geschah vor der Vorstellung, dass der Kunstreiter den Ringkämpfer betrachtete und den Seiltänzer der Muskelprotz beobachtete, wobei es ganz still war.

12. In der Zeitung stand, dass der Rocksänger den Schlagzeuger begutachtete und den Startenor der Keyboarder bewertete, wie es schon mehrmals der Fall war.
13. Es passierte mitten im Schwimmbad, dass der Sporttaucher den Brustschwimmer bemerkte und den Turmspringer der Sprintkrauler sichtete, obwohl das Wasser sehr spritzte.

14. Es geschah auf der Safari, dass der Reiseleiter den Abenteurer erspähte und den Fremdenführer der Großwildjäger erblickte, was ganz natürlich war.

15. Das Kind sagte, dass der Wagenlenker den Autoschlosser konsultierte und den Fahrzeughalter der Werkstattleiter suchte, wie es dort üblich war.

16. Man hört oft, dass der Bäcker den Händler neckt und den Müller der Käufer betrügt, wie unfair das auch scheint.

17. Der Sozialarbeiter plauderte aus, dass der Penner den Bastard tröstete und den Bettler der Krüppel bemitleidete, was sehr nett war.

18. In der Hochsaison geschah es, dass der Kneipenwirt den Meisterkoch unterstützte und den Barkeeper der Weinkenner vertrat, was sehr hilfreich war.

19. Die Urlauberin erfährt, dass der Bauer den Helfer ruft und den Farmer der Cowboy holt, was von guter Organisation zeugt.

20. Der Angestellte deutet an, dass der Staatsdiener den Werksleiter besticht und den Amtsträger der Firmenboss umschmeichelt, obwohl vieles vertuscht wird.

21. Es ist zum Vorteil des Bauherrn, dass der Techniker den Handwerker unterweist und den Anstreicher der Arbeiter instruiert, obwohl das lange dauert.

22. Der Journalist schreibt, dass der Fechter den Gegner bezwingt und den Ringer der Erzfeind besiegt, wobei großer Jubel aufkommt.

23. Es geschieht auf dem Turnier, dass der Ausbilder den Springreiter informiert und den Manager der Wettläufer benachrichtigt, wobei alles korrekt verläuft.

24. Es passiert nicht zum ersten Mal, dass der Priester den Hausarzt berät und den Pater der Heiler belehrt, was sehr großzügig ist.

25. Der Schreiber teilt mit, dass der Kaiser den Herzog verabschiedet und den König der Baron besucht, wie selbstverständlich das auch ist.

26. Die Hausfrau bekräftigte, dass der Marktschreier den Obsthändler schikanierte und den Einkäufer der Viehzüchter übervorteilte, obwohl es heftige Proteste gab.

27. Es kam schon öfter vor, dass der Kapitän den General beleidigte und den Millionär der Offizier beschimpfte, wobei es rechtliche Folgen gab.

28. Das Familienoberhaupt war sehr erfreut, dass der Bruder den Vetter umarmte und den Vater der Onkel drückte, obwohl schlechte Stimmung herrschte.

29. Es war nach Schließung der Bank, dass der Nachtportier den Landstreicher sah und den Raumpfleger der Einbrecher entdeckte, wie es manchmal zufällig passierte.

30. Der Kommissar ist sehr zufrieden, dass der Verbrecher den Kontaktmann verrät und den Betrüger der Komplize verpfeift, wie es alle erwarten.

31. Man kann sich vorstellen, dass der Bengel den Flegel hänselt und den Racker der Lümmel narrt, wobei das ganz harmlos ist. 


\section{Es passiert im Treppenhaus, dass der Rektor den Schüler erkennt und den Lehrer der Prüfling beg- rüßt, wie hektisch es auch ist.}

\section{Appendix B. Supplementary material}

Supplementary data associated with this article can be found, in the online version, at http://dx.doi.org/10.1016/ j.jml.2014.05.002.

\section{References}

Apel, J., Knoeferle, P., \& Crocker, M. W. (2007). Processing parallel structure: Evidence from eye tracking and a computational model. In S. Vosniadou, D. Kayser, \& A. Protopapas (Eds.), Proceedings of the 2nd European cognitive science conference (pp. 125-131). Great Britain: Taylor and Francis.

Arai, M., Gompel, R. P. G., \& Scheepers, C. (2007). Priming ditransitive structures in comprehension. Cognitive Psychology, 54, 218-250.

Baayen, R. H., Pipenbrock, R., \& Gulikers, L. (1995). The celex lexical database (cd-rom). University of Pennsylvania, Philadelphia, PA: Linguistic Data Consortium.

Blakemore, D. (1989). Denial and contrast: A relevance theoretic analysis of but. Linguistics and Philosophy, 12, 15-37.

Bloom, L., Lahey, M., Hood, L., Lifter, K., \& Fiess, K. (1980). Complex sentences: Acquisition of syntactic connectives and the semantic relations they encode. Journal of Child Language, 7, 235-261.

Blühdorn, H. (2008). Subordination and coordination in syntax, semantics and discourse. Evidence from the study of connectives. In C. FabriciusHansen \& W. Ramm (Eds.), Subordination versus coordination in sentence and text. A cross-linguistic perspective (pp. 59-85). Amsterdam: John Benjamins.

Branigan, H., Pickering, M. J., \& McLean, J. (2005). Priming prepositionalphrase attachment during comprehension. Journal of Experimental Psychology: Learning, Memory, and Cognition, 31, 468-481.

Callahan, S., Shapiro, L., \& Love, T. (2010). Parallelism effects and verb activation: The sustained reactivation hypothesis. Journal of Psycholinguistic Research, 39, 101-118.

Carlson, K. (2001). The effects of parallelism and prosody in the processing of gapping structures. Language and Speech, 44, 1-26.

Clément, D., \& Thümmel, W. (1996). Während als Konjunktion des Deutschen. In G. Harras \& M. Bierwisch (Eds.), Wenn die Semantik arbeitet. Klaus Baumgärtner zum 50. Geburtstag (pp. 256-276). Tübingen: Niemeyer.

Cohen, J. (1973). Eta-squared and partial eta-squared in fixed factor ANOVA designs. Educational and Psychological Measurement, 33, $107-112$.

Dubey, A., Sturt, P., \& Keller, F. (2009). A probabilistic corpus-based model of parallelism. Cognition, 109, 193-210.

Fabricius-Hansen, C., \& Ramm, W. (2008). 'Subordination' versus 'Coordination' in sentence and text (Studies in language companion series 98). Amsterdam: John Benjamins.

Frazier, L., \& Clifton, C. (2001). Parsing coordinates and ellipsis: Copy $\alpha$. Syntax, 4, 1-22.

Frazier, L., Munn, A., \& Clifton, C. (2000). Processing coordinate structures. Journal of Psycholinguistic Research, 29, 343-370.

Frazier, L., Taft, L., Roeper, T., \& Clifton, C. (1984). Parallel structure: A source of facilitation in sentence comprehension. Memory \& Cognition, $12,421-430$

Guerra, E., Marghetis, T., \& Knoeferle, P. (2013). Spatial meanings for function words? The link between conjunctions and spatial representations. In M. Knauff, M. Pauen, N. Sebanz, \& I. Wachsmuth (Eds.), Proceedings of the annual meeting of the cognitive science society (pp. 2458-2463). Austin, TX: The Cognitive Science Society.

Hale, J. (2001). A probabilistic Earley parser as a psycholinguistic model. Proceedings of the 2 nd conference of the North American chapter of the association for computational linguistics (Vol. 2, pp. 159-166). Pittsburgh: Association for Computational Linguistics.

Halliday, M. A. K., \& Hasan, R. (1976). Cohesion in English. New York: Longman.

Kehler, A. (1995). Interpreting cohesive forms in the context of discourse inference. Unpublished doctoral dissertation. USA: Harvard University.

Kehler, A. (1996). Coherence and the coordinate structure constraint. In J. Johnson, M. L. Juge, \& J. L. Moxley (Eds.), Proceedings of the twentysecond annual meeting of the berkeley linguistics society, February 16
19, 1996. General Session and Parasession on the role of learnability in grammatical theory (pp. 220-231). Berkely, CA: Berkeley Linguistics Society.

Knoeferle, P., \& Crocker, M. W. (2010). Erratum. Quarterly Journal of Experimental Psychology, First published on: 14 January 2010 (iFirst).

Knoeferle, P., \& Crocker, M. W. (2009). Constituent order and semantic parallelism in online comprehension: Eye-tracking evidence from German. Quarterly Journal of Experimental Psychology, 62, 2338-2371.

Konieczny, L., Hemforth, B., Scheepers, C., \& Strube, G. (1997). The role of lexical heads in parsing: Evidence from German. Language and Cognitive Processes, 12, 307-348.

Kutas, M. (1993). In the company of other words: Electrophysiological evidence for single-word and sentence context effects. Language and Cognitive Processes, 8, 533-572.

Lakoff, R. (1971). If's, and's, and but's about conjunctions. In C. J. Fillmore \& D. T. Langendoen (Eds.), Studies in linguistic semantics (pp. 114-149). New York: Holt, Rinehart, Winston.

Lang, E. (1977). Die Semantik der koordinativen Verknüpfung. Berlin: Akademie Verlag.

Lang, E., \& Umbach, C. (2002). Kontrast in der Grammatik: Spezifische Realisierungen und übergreifender Kontext. In A. Steube (Ed.), Sprachtheoretische Grundlagen der Kognitionswissenschaft: Sprachliches und nichtsprachliches Wissen (Linguistische Arbeitsberichte 79) (pp. 145-186). Leipzig: Institut für Linguistik der Universität Leipzig.

Ledoux, K., Traxler, M., \& Swaab, T. (2007). Syntactic priming in comprehension: Evidence from event-related brain potentials. Psychological Science, 18, 135-143.

Liversedge, S. P., Paterson, K. B., \& Pickering, M. J. (1998). Eye movements and measures of reading time. In G. Underwood (Ed.), Eye guidance in reading and scene perception (pp. 55-75). Oxford: Elsevier.

Lohnstein, H. (2005). Sentence connection as quantificational structure. In C. Maienborn \& A. Wöllstein (Eds.), Event arguments: Foundations and applications (pp. 113-138). Tübingen: Niemeyer.

Martin, A. E., \& McElree, B. (2008). A content-addressable pointer mechanism underlies comprehension of verb-phrase ellipsis. Journal of Memory and Language, 58, 879-906.

Matthiessen, C., \& Thompson, S. A. (1988). The structure of discourse and 'subordination'. In J. Haiman \& S. A. Thompson (Eds.), Clause combining in grammar and discourse (pp. 275-329). Amsterdam: John Benjamins.

Meyer, D., \& Schvanefeldt, R. (1971). Facilitation in recognizing pairs of words: Evidence of a dependence between retrieval operations. Journal of Experimental Psychology, 90, 227-234.

Pasch, R., Brauße, U., Breindl, E., \& Waßner, U. H. (2003). Handbuch der deutschen Konnektoren: Linguistische Grundlagen der Beschreibung und syntaktische Merkmale der deutschen Satzverknüpfer (Konjunktionen, Satzadverbien und Partikeln). Berlin: Walter de Gruyter.

Pickering, M. J., \& Branigan, H. (1998). The representation of verbs: Evidence from syntactic priming in language production. Journal of Memory and Language, 39, 633-651.

Pickering, M. J., \& Ferreira, V. (2008). Structural priming: A critical review. Psychological Bulletin, 34, 427-459.

Pickering, M. J., \& Garrod, S. (2004). Toward a mechanistic psychology of dialogue. Behavioral and Brain Sciences, 27, 169-225.

Poirier, J., Walenski, M., \& Shapiro, L. (2011). The role of parallelism in the real-time processing of anaphora. Language and Cognitive Processes, $27,868-886$.

Pollatsek, A., \& Well, A. D. (1995). On the use of counterbalanced designs in cognitive research: A suggestion for a better and more powerful analysis. Journal of Experimental Psychology: Learning, Memory, and Cognition, 21, 785-794.

Rayner, K. (1998). Eye movements in reading and information processing: 20 years of research. Psychological Bulletin, 124, 372-422.

Rayner, K., \& Duffy, S. A. (1986). Lexical complexity and fixation times in reading: Effects of word frequency, verb complexity, and lexical ambiguity. Memory \& Cognition, 14, 191-201.

Ross, J. R. (1967). Constraints on variables in syntax. Ph.D. thesis. Boston: MIT.

Scheepers, C., \& Crocker, M. W. (2004). Constituent order priming from reading to listening: A visual-world study. In M. Carreiras \& C. Clifton, Jr. (Eds.), The on-line study of sentence comprehension: Eyetracking, ERPs, and beyond (pp. 167-185). New York: Psychology Press.

Schenkein, J. (1980). A taxonomy for repeating action sequences in natural conversation. In B. Butterworth (Ed.). Language production (Vol. 1, pp. 21-47). London: Academic Press.

Schiffrin, D. (1987). Discourse markers. New York: Cambridge University Press. 
Schriefers, H., Friederici, A. D., \& Kuhn, K. (1995). The processing of locally ambiguous relative clauses in German. Journal of Memory and Language, 34, 499-520.

Segal, E. M., \& Duchan, J. F. (1997). Interclausal connectives as indicators of structuring in discourse. In J. Costermans \& M. Fayol (Eds.) Processing interclausal relations for the production and comprehension of text (pp. 95-120). Hillsdale, NJ: Erlbaum.

Segal, E. M., Duchan, J. F., \& Scott, P. J. (1991). The role of interclausal connectives in narrative structuring: Evidence from adults' interpretations of simple stories. Discourse Processes, 14, 27-54.

Spenader, J., \& Lobanova, A. (2009). Reliable discourse markers for contrast relations. In Proceedings of the 8th international conference on computational semantics (pp. 210-221). Stroudsburg, PA, USA: Association for Computational Linguistics.
Staub, A., \& Clifton, C. Jr., (2006). Syntactic Prediction in Language Comprehension: Evidence From Either...or. Journal of Experimental Psychology: Learning, Memory, and Cognition, 32, 425-436.

Sturt, P., Keller, F., \& Dubey, A. (2010). Syntactic priming in comprehension: Parallelism effects with and without coordination Journal of Memory and Language, 62, 333-351.

Traxler, M. J. (2008). Lexically independent priming in online sentence comprehension. Psychological Bulletin and Review, 15, 149-155.

Traxler, M. J., Morris, R. K., \& Seely, R. E. (2002). Processing subjects and object relative clauses: Evidence from eye movements. Journal of Memory and Language, 47, 69-90.

Weiner, E. J., \& Labov, W. (1983). Constraints on the agentless passive. Journal of Linguistics, 19, 29-58. 